\title{
5. Biometrie, Mendelsche Gesetze und die Frage nach dem Status von Experten: Charles Goring The English Convict (1900-1935)
}

\subsection{Die Intention der Studie}

„Relatively few scientific studies of offenders and offences have been made in this country", bemerkte 1939 der neu ernannte Direktor der London School of Economics, Alexander Carr-Saunders. ${ }^{1}$ Für ihn wie für viele andere Sozialwissenschaftler handelte es sich bei der Studie des englischen Gefängnisarztes Charles Goring The English Convict aus dem Jahr 1913 um die berühmte Ausnahme einer ansonsten beklagenswerten Regel. Tatsächlich war Gorings Arbeit die einzige nennenswerte englische Forschungsleistung großen Formats zum Thema Kriminalität vor dem Ersten Weltkrieg. Doch mit Ausnahme der Arbeiten von Piers Beirne hat diese Studie in der historischen Forschung bislang kaum nennenswerte Beachtung gefunden. ${ }^{2}$ Dabei offenbaren besonders ihr Entstehungskontext und die Rezeptionsgeschichte nicht nur die zeitgenössischen britischen Auseinandersetzungen über Anlage und Umwelt, sondern vor allem den Kampf um die Anerkennung der biometrischen Statistik als überlegene Methode zur Aufklärung solcher Fragen. Denn obgleich als neutrale und objektive wissenschaftliche Studie vorgestellt, der keine spezifische Theorie oder Vorannahme zugrunde lag, forderten die Ergebnisse von The English Convict den Widerspruch zahlreicher Kritiker heraus, die sie als ambivalent und interpretationsbedürftig wahrnahmen. Die anerkannte Wissenschaftlichkeit der Studie gewährleistete also keineswegs eine rasche Akzeptanz oder gar, wie Beirne annimmt, eine ungeheure Wertschätzung (,gargantuan esteem") ${ }^{3}$, was umso überraschender erscheinen mag, da statistische Untersuchungsmethoden zu diesem Zeitpunkt bereits großes Ansehen genossen.

1 Alexander M. Carr-Saunders, Vorwort, in: Hermann Mannheim, The Dilemma of Penal Reform, London 1939, S. 7.

2 Piers Beirne, Science, Statistics, and Eugenics in Charles Goring's The English Convict (1913), in: ders., Inventing Criminology. Essays on the Rise of Homo Criminalis, New York 1993, S. 187-224; PIERS BeIrne, Heredity vs. Environment: A Reconsideration of Charles Goring's The English Convict (1913), in: British Journal of Criminology 28 (1988), S. 315-39; erwähnt wird die Studie auch in WIENER, Reconstructing, S.357; RADZINOWICZ und Hood, The Emergence of Penal Policy, S. 20-27; Garland, British Criminology, S. 41-42.

3 Siehe BeIrne, Science, S.187. Für diese Wertschätzung erscheint schon die zeitgenössische Kritik zu ausgeprägt. Auch in Amerika experimentierten Forscher um die Jahrhundertwende mit probabilistischen Entwürfen in der Kriminologie (u. a. Ernst Freund, John Henry Wigmore, Roscoe Pound). Sie verwiesen aber stets auf den Vorsprung der Europäer, resp. der Briten, wobei dies wohl vor allem der Bewilligung von Fördergeldern dienen sollte, siehe Bernard E. Hartcourt, The Shaping of Chance: Actuarial Models and Criminal Profiling at the Turn of the Twenty-First century, in: The University of Chicago Law Review 70 1/2003), S. 105-128, hier S. 108; für den Hinweis auf Harcouts Artikel danke ich Norbert Finzsch. 
Im Grunde führte Goring in seiner Untersuchung zwei englische Forschungstraditionen fort: er verband die Ergebnisse der empirischen Forschung englischer und schottischer Gefängnisärzte und -psychiater wie Bruce Thomson oder David Nicolson mit statistischen Berechnungen, wobei er diesbezüglich auf modernste Techniken zurückgreifen konnte, die von Quetelet, besonders aber von Francis Galton und Karl Pearson weiterentwickelt worden waren. ${ }^{4}$

In seinem Aufsatz zeigt sich Piers Beirne darüber verwundert, dass sich verglichen mit Frankreich in Großbritannien erst so spät eine dezidierte Kritik an Lombrosos Theorien entwickelt habe. ${ }^{5}$ Von einer verspäteten englischen Kritik lässt sich allerdings nur dann sprechen, wenn der Entstehungskontext von The English Convict als Ausgangspunkt dieser kritischen Auseinandersetzung genommen wird. Tatsächlich gehörten aber die kritischen Einwände und die bewusste Distanzierung zahlreicher englischer Gefängnisärzte und -psychiater kurz nach dem Erscheinen von L'uomo delinquente (siehe Kap.3) ebenso wie die eigentlich als Bestätigung einer ,physiologischen' Kriminologie gedachte Entwicklung der composite photography durch Galton (siehe Kap.4) zu einer ersten Phase der kritischen Auseinandersetzung mit Lombrosos Ansätzen in England. Was allerdings in den 1880er und 1890er Jahren anscheinend unterschätzt worden war und sich auch erst im Laufe der Zeit herausstellen sollte, war die Tatsache, dass sich Lombrosos modifizierte Atavismustheorie, die sich immer stärker auf den geistig minderwertigen Verbrecher konzentrierte, hervorragend mit den zunehmenden populären öffentlichen Debatten über Degeneration, differential birth rate und national efficiency verbinden und instrumentalisieren ließ. ${ }^{6}$ In diesem Klima setzte eine zweite, diesmal von der staatlichen Verwaltung initiierte Auseinandersetzung mit Lombroso und der Italienischen Schule ein.

In den englischen Behörden hatte man sich über die Folgen eines anerkannten L'uomo delinquente für die Strafpraxis und Gefängnisarbeit nie getäuscht. Das logische Resultat dieser Theorie, so schrieb Sir Evelyn Ruggles-Brise in der Rückschau, „would be either elimination of the unfit, or the translation into the province of medicine of all legal procedur"7. Wie alle plausible erscheinenden Pseudowissenschaften erschien ihm die deterministische Kriminalanthropologie extrem gefährlich, „for it is, of course, the fact that morbid conditions are associated, to a certain degree, with crime, and, like all sensational dogmas, based on untested observation, it affected the public imagination, prone to believe that the criminal is [...] an abnormal being, the child of darkness, without pity and without shame, and with the predatory instincts of a wild beast." 8

Dass die Prison Commission schließlich ein Projekt förderte, das von ihren eigenen Gefängnisärzten durchgeführt wurde, lässt sich zunächst als Versuch wer-

4 BEIRNE, Science, S. 190.

Vgl. BeIRne, Heredity, S. 312.

Vgl. dazu Soloway, Demography and Degeneration; Forsythe, Penal Discipline, S. 154.

RugGles-Brise, Prison System, S. 199.

8 Ebd., S. 199 f. 
ten, dem allgemein beklagten Defizit einer wissenschaftlich fundierten englischen Kriminologie abzuhelfen. Doch weniger genuines Forschungsinteresse der Beamten bestimmte den Fortgang der Studie als vielmehr ihr politisches Bedürfnis, die Diskussion über den geborenen Verbrecher und damit verbundenen politischen und juristischen Implikationen ein für allemal vom Tisch zu haben. Nichts widerstrebte den Beamten in Whitehall offensichtlich mehr als die Aufweichung des Konzeptes selbstverantwortlicher Individuen und damit der Grundlagen des britischen Rechts- und Sanktionssystems. Bereits 1910, drei Jahre vor dem Erscheinen von Gorings Studie und möglicherweise nicht zufällig zum Zeitpunkt der Übernahme der Präsidentschaft des Internationalen Gefängniskongresses durch Ruggles-Brise, ließ der englische Prison Commissioner in einem Memorandum, das durch die Büros des Innenministeriums zirkulierte, keinen Zweifel an den erhofften Ergebnissen der Studie: „The Lombrosian theories of the criminal-né are exploded. Our own investigations now being conducted into the physiology of crime will, I think, fire the last shot at this deserted ship. "9

Auch Bryan Donkin, seit 1898 als Medical Commissioner in der Prison Commission tätig, bezeichnete die kriminalanthropologischen Ansätze als „matter of importance [...] not because any serious students of this subject now accept the doctrine of the so-called science of ,criminology $[\ldots]$, but because this doctrine, so much emphasised by Lombroso, Max Nordau, and others, of the hereditary nature of crime, or, in other words, of the criminal being a racial ,degenerate, is still very dominant over the public mind. It is widely popularised at the risk of producing practical effects. "10 Eine dieser bedenklichen praktischen Folgen sah Donkin bereits in den 1907 im amerikanischen Bundesstaat Indiana verabschiedeten Sterilisationsgesetzen verwirklicht. ${ }^{11}$

Selbst der Gefängnisarzt Charles Goring rechtfertigte in seiner Einleitung von The English Convict die ausführliche Auseinandersetzung mit Lombrosos Theorien damit, dass seine Theorien zwar aller wissenschaftlichen Glaubwürdigkeit entbehrten, aber nichtsdestotrotz eine große Anziehung ausübten. ${ }^{12}$ Die Öffentlichkeit kultiviere nur zu gerne einen Aberglauben, der davon bestimmt sei, dass sich Kriminelle äußerlich erkennen ließen. Lombrosos Theorie scheine „not extinct to

${ }^{9}$ Evelyn Ruggles-Brise, Memo, 18. April 1910, TNA, HO 45/13658/185668/6; siehe auch seinen Abschussvortrag vor der American Prison Association 1910 in New Willard: „[T]hat the prevailing scientific habit of ascertaining criminal tendencies through deformities of the body or disfigurement of the head [is] a fallacy." Zit. in: LesLie Shane (Hrsg.), Sir Evelyn RugglesBrise. A Memoir of the Founder of Borstal, London 1937, S. 164.

10 Bryan DonkIn, Harveian Oration 1910, zit. von Ruggles-Brise im Vorwort zu GorING, English Convict, S.8; zum Kontext dieser Rede siehe auch den Brief Donkins an Ruggles-Brise, Anm. 200 in diesem Kapitel.

11 Siehe dazu ausführlicher Kap. 5.7.

12 Siehe Goring, English Convict, S. 21: Die ersten Seiten sind eine Polemik gegen Lombroso, seine unwissenschaftlichen Praktiken und seine exzentrische Arbeitshypothese. Begründet wird die Kritik vor allem mit dem Hinweis, dass Lombroso nur aufgrund der Entdeckung von Anomalien am Schädel eines einzigen verstorbenen Räubers seine These vom Kriminellen als einer atavistischen Variante entwickelt habe. 
the public mind; and, in many influential quarters, it is dormant only, and ever ready to be revivified under official patronage."13 Fraglos teilten Prison Commission und Home Office diese Auffassung, doch mit dem Bestreben, die politischen und juristischen Implikationen von Lombrosos Kriminalanthropologie zu entkräften, hörten auch schon die gemeinsamen Ambitionen von Charles Goring und der englischen Administration auf. Denn Goring, ganz Arzt, Wissenschaftler und, so wird zu zeigen sein, begeisterter Schüler von Karl Pearson, hielt sich alles weitere, besonders in Bezug auf die eigenen Ergebnisse, offen und beschränkte sein Vorgehen zunächst auf eine fundierte Methodenkritik: „Our attack is directed not against conclusions, but against the methods by which they were reached." 14 Über Gültigkeit oder Ungültigkeit der kriminalanthropologischen Behauptungen ließen sich nach Gorings Ansicht noch gar keine Aussagen machen, da Lombroso sie nur mit unwissenschaftlichen Mitteln entwickelt habe, seine angeblichen Erkenntnisse also nie den Status wissenschaftlicher und damit zutreffender Aussagen erlangt hätten.

\subsection{Zur Entstehungsgeschichte der Studie}

1901 begann der Gefängnisarzt G.B. Griffiths in Parkhurst mit der ersten systematischen Kompilation von Daten von Gefängnisinsassen, dazu ermuntert von Bryan Donkin und dem Medical Inspector of Prisons, Herbert Smalley. Insgesamt 96 Kriterien berücksichtigte der von Smalley entworfene Erfassungsbogen. ${ }^{15}$ Ziel war der Gewinn von Massendaten ohne Rücksicht auf bestimmte Theorien oder das Favorisieren bestimmter Gefängnissysteme. Bislang verstreute und unkoordinierte Informationen aus Polizei-, Justiz- und Gefängnisakten über Vorgeschichte und kriminelle Karriere einzelner Straftäter sollten an einem festgelegten Stichtag in einem der vier an der Untersuchung beteiligten Zuchthäuser (convict prison) aufgenommen, zusammengeführt und durch neue Informationen ergänzt werden, die durch die medizinischen Eingangsuntersuchungen, im Wesentlichen anthropometrische Messungen und Befragungen durch den jeweiligen Gefängnisarzt, gewonnen wurden.

Personalveränderungen im Jahr 1902 brachten es mit sich, dass Griffiths, der Smalleys Position als Medical Inspector of Prisons übernahm und später als Medical Commissioner der Prison Commission selbst angehörte, durch Dr. Charles Goring, Deputy Medical Officer in Parkhurst, ersetzt wurde. Von den 3000 Häft-

13 Ebd., S. 19.

14 Ebd., S. 19, Hervorhebung im Original.

15 Siehe Edwin D. Driver, Charles Buckman Goring (1870-1919), in: Herman Mannheim (Hrsg.), Pioneers in Criminology, 2. erw. Aufl. Montclair/NJ 1973, S.429-442; zur Entstehungsgeschichte siehe auch BEIRNE, Science, S. 190-194; GINA LOMBroso-FERrERO, The Results of an Official Investigation made in England by Dr. Goring to test the Lombroso Theory, in: Journal of the American Institute of Criminal Law and Criminology 5 (2/1914), S. 207-223, hier S. 207-209. 
lingen, deren Daten in die Untersuchung einflossen, untersuchte und verzeichnete Goring mehr als die Hälfte selbst. Goring war es auch, der die enorme Masse an Daten aus allen vier beteiligten Gefängnissen systematisierte und die Angaben in den Fragebogen durch statistische Reduktion zur weiteren Bearbeitung und Auswertung vereinfachte. Das Sammeln der Daten wurde Ende 1907 abgeschlossen, 1908/1909 erschienen sie in Buchform. ${ }^{16}$ Sie stellten nach Gorings Aussagen das Rohmaterial dar, dessen Auswertung dazu dienen sollte: „To clear from the ground the remains of the old criminology, based upon conjecture, prejudice, and questionable observation." Es ging also um die endgültige Beseitigung eines kriminellen Typs Lombrosischer Prägung. Es ging aber auch um neues Wissen über den Kriminellen, das auf Fakten basieren sollte, die wissenschaftlich erworben wurden. Die solcherart gewonnenen Fakten sollten dann „by virtue of their own established accuracy, unimpeachable conclusions" 17 ermöglichen.

Spätestens mit der Publikation der Datenkonvolute wurde offensichtlich, dass zur weiteren Bearbeitung professionelle mathematische Hilfe benötigt wurde. Goring wurde für zweieinhalb Jahre freigestellt, um die Daten im biometrischen Labor am University College in London unter der Leitung von Karl Pearson und seinen Mitarbeitern mit Hilfe statistischer Verfahren auszuwerten. ${ }^{18}$ Den Kontakt zum Labor vermittelte Bryan Donkin, der sowohl Karl Pearson als auch Walter Frank Raphael Weldon, ${ }^{19}$ den Mitherausgeber der vom Labor lancierten Zeitschrift Biometrika, ${ }^{20}$ persönlich kannte. An Massendaten solchen Ausmaßes „unprecedented in criminal literature“,21 wie Karl Pearson später schrieb - waren die Mitarbeiter im Labor äußerst interessiert, denn solche umfänglichen Datensammlungen waren Anfang des Jahrhunderts in England noch eine Seltenheit, da

16 Charles Goring, On the Inheritance of the Diathesis of Phthisis and Insanity. Studies in National Deterioration, no. 5, Biometric Laboratory, University College, London 1909; vgl. BEIRNE, Heredity, S. 322 .

17 Beide Zitate: Goring, English Convict, S. 18.

18 Siehe Beirne, Heredity, S. 323-325; Karl Pearson, Charles Goring and His Contribution to Criminology. Introduction, in: Charles Goring, The English Convict. A Statistical Study, 2. gekürzte Aufl. London 1919, S. ix-xvi, hier S. xi.

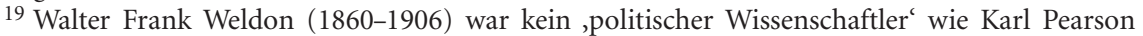
(1857-1936); er bezweifelte auch, dass sich Anlage und Umwelt säuberlich zur Analyse trennen ließen, was wiederum Galton verärgerte, dessen Arbeit wesentlich von einer solchen Annahme ausging, vgl. Weldon an Pearson, 16. Oktober 1904, Pearson Papers 625, University College London, erwähnt in: MACKenzIE, Sociobiologies, S.271; die skeptische Haltung Weldons erklärt wiederum die Nähe zu Donkin (siehe weiter unten in diesem Kapitel); zum größeren Einfluss (im Gegensatz zu Galton), den Weldon auf Pearson ausübte - Pearson mathematische Arbeiten wurden wesentlich durch Weldons Entdeckungen beeinflusst - siehe Eileen Magnello, Karl Pearson's Gresham lectures. W.F.R. Weldon, Speciation and the Origin of Pearsonian Statistics, in: British Journal for the History of Science 29 (1996), S. 43-63, bes. S. 45-47 (mit ausführlichen bibliographischen Angaben).

${ }^{20}$ Biometrika. A Journal for the Statistical Study of Biological Problems. Edited in consultation with Francis Galton by W.F.R. Weldon, Karl Pearson und Charles B. Davenport. Die Zusammenarbeit mit Davenport endete nach wenigen Jahren über den Methodenstreit zwischen Mendelianern und Biometrikern (vgl. Kap. 5.3.); Donkin und Pearson gehörten dem progressiven Men's and Women's Club (1885) an, siehe GIllHam, Francis Galton, S. 273.

21 Pearson, Goring, S. xi. 
keine Institutionen existierten, die sie systematisch sammelten. ${ }^{22}$ Allerdings war zu diesem Zeitpunkt nur eine Handvoll Experten in der Lage, multiple Daten größeren Umfangs überhaupt adäquat zu bearbeiten. ${ }^{23}$

Karl Pearson und die Arbeitsweise seines biometrischen Labors sollten einen maßgeblichen Einfluss auf die endgültige Version und Präsentation von Gorings The English Convict ausüben. Deutlich wurde dies an drei längeren Abschnitten in der Studie selbst, in denen die allgemeinen Grundsätze erläutert wurden, auf denen die Arbeit aufbaute. Im einführenden Kapitel The Science of the Criminal ging es um die Erklärung der biometrischen Statistik, im Abschnitt über The Influence of the ,Force of Circumstances' on the Genesis of Crime legte Goring die grundverschiedenen Konzepte von environment dar, mit denen Sozialreformer und Biometrikern arbeiteten, und im zentralen letzten Kapitel unter der Überschrift The General Problem of Heredity ging es schließlich um die Frage, wie sich Wissenschaftler seriös und legitim dem biologischen Problem der Vererbung nähern könnten. Dass es sich bei allen drei Erörterungen nicht einfach nur um wissenschaftlich neutrale Vorbemerkungen handelte, sondern um programmatische Stellungnahmen, die eine direkte Kampfansage an die Anhänger der Mendelschen Vererbungslehre und zugleich an die Gruppe ,naiver' Sozialreformer und Politiker darstellte, wird deutlich, wenn vor der Analyse der eigentlichen Studie ein kurzer Blick auf das biometrische Labor und die wissenschaftlichen Kontroversen geworfen wird, in die dieses Labor im Vorfeld der Studie zu The English Convict involviert war.

\subsection{Evolution by Jumps: die Kontroverse zwischen Biometrikern und Mendelianern}

In der historischen Forschung hat die in England um die Jahrhundertwende geführte heftige Debatte zwischen den Anhängern Mendels und seinen Gegnern, den Biometrikern um Karl Pearson, seit einigen Jahren Beachtung gefunden. ${ }^{24}$

22 Vergleichbare Datenmengen konnte zu diesem Zeitpunkt nur das Militär erheben.

231904 hatte G.B. Griffiths die ersten Ergebnisse aus den Untersuchungen in Biometrika veröffentlicht, siehe Biometrika 3 (1904); zur Vorgeschichte der Studie siehe Ruggles-Brise, Preface, S.6; zur Weiterentwicklung der Statistik durch Pearson siehe Donald A. MacKenZie, Statistics in Britain, 1865-1930. The Social Construction of Scientific Knowledge, Edinburgh 1981, S. 73-93; STigler, History of Statistics, Kap. 10: Pearson and Yule, S. 326-361; GillhaM, Francis Galton, S. 269-285; DeSROSIÈRES, Politik der großen Zahlen, S. $147 \mathrm{f}$.

24 Eine ausführliche Bibliographie zu dieser Kontroverse findet sich in Donald MacKenzie, Sociobiologies in Competition: the Biometrician - Mendelian Debate, in: Webster (Hrsg.), Biology, S. 243, Anm. 1; zu den Details der Auseinandersetzung siehe Donald MacKenzie und S.B. BARNES, Biometriker versus Mendelianer: eine Kontroverse und ihre Erklärung, in: Kölner Zeitschrift für Soziologie und Sozialpsychologie, Sonderheft 18 (1975), S. 165-196; ebenfalls anschaulich dazu die Kapitel ,Evolution by Jumps' und ,The Mendelians Trump the Biometricians' in: Gillham, Francis Galton, S. 286-323; die zwei Kapitel ,Discontinuity in Evolution' und ,Biometry', in: Bulmer, Francis Galton, S. 299-331; Robert Olby, The Dimensions of Scientific Controversy: The Biometrician-Mendelian Debate, in: British Journal for the History of Science 22 (1988), S. 299-320; MaGnelLo, Karl Pearson's Gresham lectures, S. 49-63; 
Wissenschaftshistoriker schreiben dieser Kontroverse eine wichtige Rolle in der Entwicklung der modernen Genetik und der synthetischen Evolutionstheorie zu. ${ }^{25}$ Für die Wissenschaftskultur jener Jahre stellt sie darüber hinaus eine englische Besonderheit dar, denn das von Pearson und seinen Mitarbeitern betriebene statistische Studium biologischer Probleme kannte kein kontinentaleuropäisches oder amerikanisches Pendant. Dem Einfluss des biometrischen Labors wird es zugeschrieben, dass sich die Beschäftigung mit Mendel in England verzögerte. Gerade die Einbindung der Biometrie in ein Regierungsprojekt ist ein Beispiel dafür, wie groß die öffentliche Wertschätzung war, die statistischen Verfahren entgegen gebracht wurde. Zugleich erklärt die Kontroverse auch, warum The English Convict keine neutrale wissenschaftliche Abhandlung, sondern sowohl eine wissenschaftliche als auch politische Streitschrift darstellt.

Die führenden Protagonisten dieser Debatte waren drei junge, ambitionierte und noch am Anfang ihrer Karriere stehende Wissenschaftler: Karl Pearson, Walter Frank Raphael Weldon und William Bateson. Alle drei gehörten der ersten Forschergeneration nach Darwin an, alle drei waren überzeugte Darwinisten, alle drei erhielten jedoch ihre wesentlichen Impulse durch Galtons statistische Arbeiten, d.h. dieses "triumvirate of mathematically inclined scientists“ 26 spezialisierte sich auf die statistische Analyse biologischer Phänomene. Der mathematisch hochbegabte Pearson verfeinerte Galtons korrelative Statistik, wobei es ihm primär um die statistische Verifikation von Darwins Evolutionstheorie ging. Pearson bekleidete sowohl einen Lehrstuhl für Angewandte Mathematik und Mechanik als auch, seit 1892, einen Lehrstuhl für Geometrie am University College in London. ${ }^{27}$

Der Meeresbiologe Walter Frank Raphael Weldon, seit 1891 Kollege von Pearson am University College, nutzte die von Galton und Pearson entwickelte statistische Methode, um sie auf seine umfangreichen Massendaten von Krabben und Garnelen anzuwenden. ${ }^{28}$ Auf Anregung Galtons entstand Mitte der 1890er Jahre um Pearson und Weldon herum eine biometrische Schule, die sich mit einem kleinen Kreis ausgezeichneter Mitarbeiter umgab. ${ }^{29}$ Richard Soloway beschreibt

BeIRne, Science, S. 194-199; P. Froggatt und N.C. Nevin, The „Law of Ancestral Heredity“ and the Mendelian-Ancestrian Controversy in England, 1889-1906, in: Journal of Medical Genetics 8 (1971), S. 1-36.

25 Vgl. Daniel J. Kelves, Genetics in the United States and Great Britain 1890-1930: A Review with Speculations, in: Charles Webster (Hrsg.), Biology, Medicine, and Society, 1840-1940, Cambridge 1981, S. 193-215; einer der Architekten dieser Sythese war der deutschstämmige ERnST MAYR, vgl. dazu seine programatische Arbeit: ders., Systematics and the Origin of Species, New York 1949; Robert J. Richards, Darwin and the Emergence of Evolutionary Theories of Mind and Behavior, Chicago und London 1987, S. 544: „In the 1930s and 1940s, Darwinian theory was revitalized and merged with Mendelian genetics in the synthesis that remains dominant today."

26 Gillham, Francis Galton, S. 9.

$27 \mathrm{Zu}$ Pearsons Vorlesungen siehe STIGLER, History of Statistics, S. 326; zur Berufung auf den Sir Thomas Gresham Lehrstuhl für Geometry siehe PeArson, Science, S.XI; Magnello, Karl Pearson's Gresham Lectures, S. 43-45.

$28 \mathrm{Zu}$ W.F.R. Weldons Forschungen siehe Bulmer, Francis Galton, S. 301-308.

${ }^{29}$ Dazu gehörten David Heron und Ethel Elderton. 
treffend, welchen Übergang die Entwicklung der biometrischen Schule für die Wissenschaftskultur Englands bedeutete:

It was a blending of the older Victorian tradition of the precocious, eclectic, selfsupporting scientific amateur with the new institutionalized professionalism and specialization that increasingly characterized science in the late nineteenth and early twentieth centuries. After 1900 biometrics, supported by its own scholarly journal, Biometrika, rapidly become synonymous with Pearson's statistical laboratory at University College. ${ }^{30}$

Der Dritte im Bunde, William Bateson, war ein durch eine Verwaltungsstelle am St. John's College in Cambridge finanziell unabhängig arbeitender Biologe, der sich auf andere Weise von Galtons Natural Inheritance (1888) hatte inspirieren lassen. Galton hatte festgestellt, dass die Nachkommen großer Menschen in ihrer eigenen Größe wieder stärker zum errechneten Mittelwert der gesamten Population tendierten. Das würde aber bedeuten, dass durch diese regression to the mean eine fortschreitende Evolution durch natürliche Selektion eigentlich vereitelt werden würde. Galton entwickelte darauf hin die Idee der Evolution als eines Fortschreitens durch den sprunghaften Wechsel der Gattung ,from one position of organic stability to another",31 ein diskontinuierlicher Wechsel, der die von ihm festgestellte Rückkehr zum Mittelwert verhinderte und neue Arten entstehen ließ. Galton sprach dabei von „sports“ oder „saltations“, 32 kannte aber noch keine materielle Basis für diesen Mechanismus. Diese Sprünge hatte Bateson bereits selbst vermutet. Für ihn bedeuteten diese diskontinuierlichen Varianten, die eben nicht nur als graduelle Abweichungen vom Durchschnitt einer Art angesehen werden konnten, eine ernste Schwierigkeit für Darwins Evolutionstheorie. Wie sollte sich natürliche Selektion progressiv durch ausgewählte kleine Änderungen innerhalb einer Art auswirken, wenn doch Diskontinuität, wie auch immer bewerkstelligt, als eine so viel geeignetere Quelle von Diversität erschien?

Pearson, Weldon und die Mitarbeiter des Biometrischen Labors - nicht aber Francis Galton - hielten schon aufgrund ihrer favorisierten Methode, der Normalverteilung um einen statistisch errechneten Mittelwert (bell curve), an einem orthodoxen Evolutionsmodell fest und favorisierten einen Prozess kontinuierlicher Selektion vorteilhafter Varianten. Wenn z. B. Größe einen selektiven Vorteil bot, dann würde die Durchschnittsgröße einer Population von einer Generation zur nächsten graduell steigen, weil innerhalb der Elterngeneration diejenigen, die körperlich größer waren, zahlreicher überlebten und proportional mehr Nachkommen zeugen konnten.

1894 publizierte Bateson seine Materials for the Study of Variation, eine umfangreiche Materialsammlung, die über 800 diskontinuierliche Variantenarten

30 SolowaY, Demography, S. 28: „Eugenics undoubtedly gained considerable authority and respectability in educated circles by its association with an important university and its promulgation by academicians and professional scientists."

31 Zit. nach Gillham, Francis Galton, S. 292.

32 Vgl. ebd., S. 286, S.289. Siehe dazu auch Galtons Besprechung des Buches Materials von Bateson, in: Mind (Neue Serie) 3 (1894), S. 362-372, hier S.368: „no variaion could establish itself unless it be of the character of a sport, that is, by a leap from one position of organic stability to another." 
verzeichnete, die ihm in der Natur aufgefallen waren. ${ }^{33}$ Anders als Galton schrieb Bateson diesen diskontinuierlichen Arten die entscheidende Bedeutung im evolutionären Prozess zu, nicht den graduellen Abweichungen innerhalb einer Spezies. ${ }^{34}$ Neue Arten waren Ausdruck von Entwicklungsbrüchen und qualitativ unterschieden von jeder anderen Art. Den Ursprung dieser distinkten, abrupt entstandenen neuen Arten schrieb Bateson nicht der Umwelt zu, da diese ihren Zustand nur graduell und langsam änderte. ${ }^{35}$ Die Ursache musste in den Varianten selbst gesucht werden: „The first question which the Study of Variation may be expected to answer relates to the origin of that Discontinuity of which Species is the objective expression. Such Discontinuity is not in the environment; may it not, then, be in the living thing itself. "36 Bateson war sich sicher, dass wirklicher evolutionärer Vorteil nur durch seltene und zum großen Teil unvorhersehbare Diskontinuitäten zustande kam: „it is upon mutational novelties, definite favourable variations, that all progress in civilisation and in the control of natural forces must depend. " 37

Diese unkalkulierbaren ,Sprünge` entzogen sich aber schon per Definition den biostatistischen Berechnungen. Entsprechend harsch fiel Weldons und Pearsons Kritik an Batesons Materials aus. ${ }^{38}$ Weldon lobte zwar Batesons Eifer und Fleiß, glaubte aber, die vielen Beispiele hätten ihn zu falschen Schlüssen verleitet. Bateson gehe vor allem von einem falschen Umweltkonzept aus, er nehme Kontinuität an, wo rascher Wechsel nicht ungewöhnlich sei. Außerdem scheine Bateson nur die physikalische Umwelt in Betracht zu ziehen und lasse außer Acht, dass Darwin und Alfred Wallace als Umwelt eben auch andere Lebewesen betrachtet hätten. Pearson tat Batesons Beispiele später sogar als „useful catalogue of museum and collector's deviations from ,type “" ab. ${ }^{39}$ Die Debatte zwischen Weldon und Bateson avancierte zur zentralen Debatte auf der Jahrestagung der Royal Society im Februar 1895 und erfuhr eine öffentliche Fortsetzung in Form von Leserbriefen in der Zeitschrift Nature. ${ }^{40}$ Über diesen Disput ging die persönliche Freundschaft zwischen Weldon und Bateson, die gemeinsam in Cambridge studiert hatten, in die Brüche.

Der Kontroverse, die sich dann zwischen der biometrischen Schule und Bateson nach der Wiederentdeckung der Mendelschen Vererbungsgesetze um die Jahrhundertwende durch die Entdeckungen dreier unabhängig voneinander ar-

33 William Bateson, Materials for the Study of Variation, Treated with Especial Regard to Discontinuity in the Origin of Species, London 1894.

34 Siehe MacKenzie, Sociobiologies, S. 257.

35 Vgl. dazu Gillham, Francis Galton, S. 290.

36 Bateson, Materials, S. 15, S. 17, zit. nach Gillham, Francis Galton, S. 292, Hervorhebung S.F.

37 Zit. nach MacKenZIE, Sociobiologies, S. 282.

38 Vgl. Walter Frank Raphael Weldon, The Study of Animal Variation, in: Nature 50 (1894), S. $25 \mathrm{f}$.

${ }^{39}$ Karl Pearson, On the Fundamental Conceptions of Biology, in: Biometrika 1 (1902), S. 320344, hier $329 f$.

40 Siehe Gillham, Francis Galton, S. 296-297. 
beitender Biologen auf dem Kontinent entzündete, ${ }^{41}$ war eine Fortsetzung der älteren Auseinandersetzung über die Natur evolutionärer Änderungen und die Frage über die korrekte Art und Weise, wie Evolution studiert und interpretiert werden sollte. Donald MacKenzie und andere machen zu Recht darauf aufmerksam, dass die Fragen zu Mendels Vererbungsgesetzen und die Probleme evolutionärer Diskontinuitäten nicht zwangsläufig hätten miteinander diskutiert werden müssen. In England wurden beide wissenschaftlichen Probleme aber aufgrund der personellen Verquickung von Anfang an eng miteinander verbunden. ${ }^{42}$

Als der niederländische Biologe Hugo de Vries den ersten Band seiner Mutationstheorie $^{43}$ an William Bateson mit dem Hinweis sandte, Teile der Arbeit basierten auf dessen Vorarbeiten, fühlte sich der Cambridger Biologe umgehend in seiner Annahme von evolutionären ,Sprüngen' als Schlüssel zum Evolutionsprozess bestätigt. ${ }^{44}$ Neue Arten entstanden durch spontane, individuelle Sprünge, wie de Vries sie durch die Bestrahlung der Keimzellen von Nachtkerzen mit Röntgenstrahlen ausgelöst hatte. Sie konnten somit experimentell erzeugt und beobachtet werden. Während de Vries aber zu dem Schluss kam, dass sich solche Mutationen in der Regel für Organismen nachteilig auswirkten und zudem morphologisch nur von geringem Ausmaß waren, und deshalb im Zuge dieser Überlegungen von Mendel Abstand nahm, ${ }^{45}$ brachte Bateson beides zusammen: evolutionäre ,Sprünge' und die Annahme, dass diese Veränderungen nach den Mendelschen Gesetzen an die nächste Generation weitergegeben wurden. Mendels Theorie lieferte ihm eine Erklärung für diesen Mechanismus.

Pearson und Weldon ahnten zwar auch, dass da eine mögliche Verbindung existieren könnte. Um ihres eigenen wissenschaftlichen Ansatzes willen, der wesentlich vom Modell gradueller Veränderungen abhing, verwarfen sie aber die Mendelschen Gesetze als Erklärungshypothese und damit zugleich die experimentelle Annäherung an das Problem von Vererbung und Variation. ${ }^{46}$ Die erste Ausgabe der Zeitschrift Biometrika enthielt eine lange detaillierte Kritik Weldons an Mendels Gesetzen. ${ }^{47}$ Dessen Reinheitskriterien erschienen dem Biometriker fragwürdig, sie seien nur ein hypothetisches Konstrukt und keineswegs eine ein-

${ }^{41}$ Hugo de Vries, Carl Erich Correns und Erich von Tschermak-Seysenegg hatten unabhängig voneinander durch ihre Forschungen Mendels Vererbungslehre wiederbelebt.

42 Siehe MacKenzie, Sociobiologies, S. 258, Anm. 49.

${ }^{43}$ Hugo de VRIEs, Die Mutationstheorie, Leipzig 1901-1903.

44 Zum Einfluss Batesons auf de Vries siehe Garland E. Allen, Hugo de Vries and the Reception of the Mutation Theory, in: Journal of the History of Biology 2 (1969), S. 65-69; MACKENZIE, Sociobiologies, S. 257.

${ }^{45} \mathrm{Da}$ de Vries die Wandlung in neue Arten auf dem Wege von Mutationen nicht für möglich hielt, griff er auf die Theorie einer nur Organismen zukommenden ,Formbildungskraft ${ }^{c}$ (Neovitalismus) zurück. Anders als dieser Neovitalismus erwies sich aber die Mutationstheorie als weitreichender und fruchtbarer, siehe HUGO DE VRIES, The Mutation Theory [1901], 2 Bde London 1910; M.J. KotTler und N.B. Davies, Hugo de Vries and the Rediscovery of Mendel's Laws, in: Annals of Science 36 (1979), S. 517-538.

46 Siehe Searle, Eugenics and Politics, S. 18.

47 Walter Frank Raphael Weldon, Mendel's Laws of Alternative Inheritance in Peas, in: Biometrika 1 (1902), S. 228-254; siehe dazu auch GILLHAM, Francis Galton, S. 309. 
fache empirische Beschreibung. Zwischen glatt und faltig, gelb und grün gebe es tausend Zwischenstufen, und wer garantiere, dass es sich bei den von Mendel zugrunde gelegten Erbsensorten um reine Arten und nicht nur um Abweichungen und Varianten einer Art handele? Die Biometriker störte der hypothetische Charakter des Modells. Außerdem erschien es zu einfach: Bislang gab es ja nur einige Merkmale, die auf diese Weise untersucht werden konnten. Komplexeren Merkmalen konnte man damit nicht gerecht werden. Was war mit unregelmäßiger Dominanz, mit unvollkommener Rezessivität, mit der Latenz von elterlichen Merkmalen? Fragen dieser Art, so kritisierte Weldon, die für Mendels Hypothese zentral waren, könnten ohne Rückgriff auf feinere und bessere Methoden der Beschreibung und Beobachtung nicht beantwortet werden. ${ }^{48}$ Wer wie die Biometriker im Studium der Vererbungsprozesse die Basis für eine Anwendungswissenschaft mit Vorhersagepotential suchte, für den schienen die experimentellen Verfahren mit ihren theoretischen Extrapolationen eine Zumutung. Der flexible deskriptive Apparat der Biometriker konnte dagegen multiple Faktoren und eine schier endlose Menge an Pänomenen in den Blick nehmen:

[T] he whole problem of evolution is a problem of vital statistics - a problem of longevity, of fertility, of health, and of disease, and it is as impossible for the evolutionist to proceed without statistics, as it would be for the Registrar-General to discuss the national mortality without enumeration of the population, a classification of deaths, and a knowledge of statistical theory. Yet this $[\ldots]$ is precisely what the school of biologists represented by Mr. Bateson are attempting to do. ${ }^{49}$

Im Unterschied zu den Experimentalbiologen besaßen die Biometriker kein explizites theoretisches Modell der Vererbung. Sie beschäftigten sich mit quantitativ messbaren Merkmalen und deren Relationen zu anderen Faktoren. Dabei ging es in erster Linie um Beschreibung statistischer Regelmäßigkeiten im Auftreten von phänotypisch erkennbaren Eigenschaften beim Übergang von der Elterngeneration auf die Nachfolgegeneration. Während die Mendelianer an einem Ja oder Nein des Auftauchens einer Eigenschaft in der Folgegeneration interessiert waren und den dahinter wirkenden Mechanismus zu entschlüsseln suchten, fragten Biometriker nur nach dem Ausmaß, der Intensität, der Frequenz oder Häufigkeit der Eigenschaft und drückten das Resultat numerisch über einen Korrelationskoeffizienten aus. Die meisten von Pearson und seinen Mitarbeitern durchgeführten Messungen und Berechnungen von Korrelationen bestimmter menschlicher Eigenschaften auf der einen Seite und der sie beeinflussenden Anlage- bzw. Vererbungs- und Umweltfaktoren auf der anderen hatte das Team sehr früh davon überzeugt, dass die Intensität der Vererbungs- d. h. Anlagefaktoren um ein fünfbis zehnfaches höher lag als der Einfluss von Umweltfaktoren. ${ }^{50}$

48 Zit. nach Gillham, Francis Galton, S. 321 (Brief in The Times vom 20.8.1904).

49 Karl Pearson, On the Fundamental Conceptions of Biology, in: Biometrika 1 (1901/1902), S. 320-355, hier S. 320 .

50 Siehe dazu SEArle, Eugenics and Politics, S. 47 (Anmerkung 7); Biometrika 11 (1915), S. 12: "There is much evidence to show that the chief mental characters flow from congenital and hereditary potentialities [...] intellectual power is not a product of environment." 
Bateson entwickelte sich unterdessen zum führenden Mendelianer in England. ${ }^{51}$ Er und seine Mitarbeiter, darunter Reginald C. Punnett, konzentrierten sich auf Experimente mit Pflanzenhybriden und theoretischen Modellen, die auf der Annahme von diskreten elementaren Erbfaktoren (Genotypen) basierten. ${ }^{52}$ Später sollten diese Faktoren als Gene firmieren, doch zum Zeitpunkt der Kontroverse zwischen Mendelianern und Biometrikern war der Mendelsche Erbfaktor nur eine hypothetische Größe. Für Experimentalbiologen war diese Größe allerdings ein entscheidender Gewinn, wie Bateson, sehr zum Ärger von Pearson und Weldon, zum Tagungsauftakt der British Association for the Advancement of Science im August 1904 in Cambridge in seiner Präsidentenansprache betonte. ${ }^{53}$ Er zeigte sich darüber verwundert, dass sich die Rezeption von Mendels Entdeckung als so schwierig und kontrovers herausgestellt habe. Wie die Gravitationstheorie eine große Bandbreite von Fakten in ein kohärentes Ganzes gebracht habe, so habe es Mendels Theorie vermocht, die bislang inkohärenten und widersprüchlichen Fakten der Vererbung zu koordinieren. ${ }^{54}$ Bateson brach eine Lanze für die experimentelle Biologie und wurde zugleich zum Wortschöpfer ihrer künftigen Forschungsrichtung: "The breeding-pen is to us what the test-tube is to the chemist - an instrument whereby we examine the nature of our organisms and determine empirically what for brevity I may call their genetic properties. “55 Zwei Jahre später, 1906, prägte Bateson formal den Begriff genetic für seine Form der Wissenschaft, 1908 übernahm er den ersten Lehrstuhl für Genetik in Cambridge. ${ }^{56}$

Was die neue Mutationstheorie und die Diskussion über die Mendelsche Vererbungslehre bewirkten, war die Aufwertung der experimentellen Biologie. An ihr entzündete sich ein Streit nicht nur um Inhalte, sondern um die richtige und angemessene Methode. ${ }^{57}$ Biometriker hielten die Beschreibung von Regelmäßigkeiten phänotypischer Ähnlichkeiten für die bestmögliche Annäherung an das Problem der Vererbung. Die Mendelianer hingegen hatten Vertrauen in ein theoretisches Modell, auch wenn damit bislang nur eine kleine Auswahl beobachtbarer Phänomene erklärt werden konnte. Natürlich war es auch, wie Donald MacKenzie

51 Siehe dazu Robert Cecil Olby, William Bateson's introduction of Mendelism to England: A Reassessment, in: British Journal for the History of Science 20 (1987), S. 399-420.

52 Die Debatte zwischen den Biometrikern und den Mendelianern wurde natürlich auch außerhalb Englands rezipiert, z. B. in den USA im Kontext rassenideologischen Überlegungen: W.E. CAstle, The Laws of Heredity of Galton and Mendel, and Some Laws Governing Race Improvement by Selection, in: Proceedings of the American Academy of Arts and Sciences 39 (1903), S. 223-242.

53 Siehe dazu MacKenzie, Sociobiologies, S. 246; Gillham, Francis Galton, S. 320 f.

54 Zit. nach Gillham, Francis Galton, S. 322.

55 William Bateson, Presidential Address to the Zoological Section, British Association: Cambridge Meeting 1904, hier zit. nach BeATRICE BATESON (Hrsg.), William Bateson, FRS, Naturalist: his Essays and Addresses, together with a short account of his life, Cambridge 1918, S. 233-59, hier S. 243, Hervorhebung S.F.

56 William Bateson, A Text-Book of Genetics (Rezension des Buches von Lotsy Vorlesungen über Descendenz-Theorien, 1. Theil), in: Nature 74 (1906), S. 146; William Bateson an Adam Sedgwick, 18. April 1905, in: Bateson, Naturalist, S. 93; offiziell dann in: NATURE 46 (1906), S. 1.

57 SOLOWAY, Demography, S. 28. 
ausführt, ein Streit um die „vested interests of scientists with different types of skills“. ${ }^{58}$ Während Bateson nichts von Mathematik verstand, verstand Pearson nichts von Biologie, und es wäre für beide schwer vorstellbar gewesen, Theorien zu unterstützen, die die eigenen Fähigkeiten bzw. Begabungen und die damit verbundenen Forschungstätigkeiten abgewertet hätten. ${ }^{59}$ Die Inkommensurabilität der Positionen führte zu Kommunikationsschwierigkeiten. Beide Lager konnten sich offensichtlich nicht einmal auf die Natur des Problems verständigen, welches sie zu lösen beabsichtigten. „Mr Bateson and I do not use the same language“, 60 stellte Pearson indigniert fest. Und Bateson, der schon früh bekannt hatte, dass er mit Mathematik immer seine Schwierigkeiten gehabt habe ${ }^{61}$ gab mit Blick auf Pearson offen zu: „his treatment is in algebraical form and beyond me.“62

Was die öffentliche Rezeption des Streites betraf, so befanden sich die Biometriker im Nachteil. Nur die mathematisch Begabtesten konnten Pearsons elaborierten Theorien folgen, während die Einfachheit des Mendelschen Modells rasch neue Anhänger fand. Nicht zuletzt die Stammbaumtafeln der Eugenics Education Society zeigten größere Nähe zu den einfachen Ableitungen Mendels als zu den Normalverteilungskurven der Biometriker. ${ }^{63}$ Einer von Weldons Schülern, A. D. Darbishire, mutierte nach der Durchführung einer aufwendigen Forschungsserie, für die Weldon die Berechnungen gemacht hatte, zu einem überzeugten Mendelianer, und der Amerikaner Charles Davenport, anfänglich ganz begeistert von Pearsons Ansatz, verabschiedete sich von der biometrischen Statistik und damit zugleich von seiner Mitherausgeberschaft von Biometrika, um sich, ganz auf Mendel einschwenkend, auf Zuchtexperimente zu konzentrieren. ${ }^{64}$ Als 1906 Weldon überraschend an einer Lungenentzündung starb, blieb Pearson mit einer Handvoll Mitarbeiter am University College zurück. 1909 erweitere der Gefängnisarzt Charles Goring den Kreis der Mitarbeiter für zweieinhalb Jahre.

\section{4. „Cher Maître": Charles Goring und Karl Pearson}

Das Arbeiten mit Karl Pearson war für den Gefängnisarzt Charles Goring eine Offenbarung. Neben dem Einfluss von Francis Galton und Adolphe Quetelet sei seine Arbeit, so schrieb Goring in The English Convict, wesentlich von der stimu-

58 MaCKenZIE, Sociobiologies, S. 262.

59 Vgl. ebd., S. 251-256; Bateson erklärte sogar, Galton sei aufgrund seiner mathematischen Ausbildung nicht in der Lage gewesen, Mendel zu entdecken (ebd., S. 252, Anm. 28).

60 Pearson, On the Fundamental Conceptions of Biology, S. 331.

61 „Mathematics were my difficulty“, BATESON, Naturalist, S.10; zu Batesons mathematischer Schwäche auch Kelves, Genetics in the United States and Great Britian, S. 198.

62 Zit. nach MACKenZIE, Sociobiologies, S. 255.

63 Vgl. dazu die Einschätzung von MonTAgu CrackANTHORPe (erster Präsident der EES), der die Biometrie für zu kompliziert hielt: „[T]he biometrical method is based on the ,law of averages', which again is based on the theory of probabilities', which again is based on mathematical calculations of a highly abstract order." Zit. nach GILLHAM, Francis Galton, S. 341.

64 Siehe ebd., S. 323. 
lierenden Persönlichkeit und den brillanten mathematischen Forschungen eines einziges ,Meisters' inspiriert worden, „who has recently reduced to order the previous chaos of statistical science."65 Gemeint war natürlich Karl Pearson. Persönlich, so bekannte Goring 1918 in einer öffentlichen Auseinandersetzung mit dem Medical Prison Commissioner Horatio Donkin, habe er nie eine klare und deutlich fokussierte Ansicht über das Problem von Anlage und Umwelt besessen bis er es durch das Medium von Korrelation und Wahrscheinlichkeitsrechnung (correlation and prediction formula) habe betrachten können. ${ }^{66}$ Goring war davon überzeugt, dass die Biologie durch die Biometrie als angewandte Mathematik vor allem an terminologischer Präzision gewonnen habe: Mathematik bringe den zusätzlichen Vorteil mit, die häufig feststellbare Vagheit verbalen Ausdrucks durch einen Symbolismus zu ersetzen, dessen Bedeutung stets präzise, unveränderbar und nie widersprüchlich sei. ${ }^{67}$ Für Goring war Biologie durch die Einbeziehung der Mathematik der Objektivität reiner Wissenschaften näher gerückt.

Goring war, was die Hinwendung zu Karl Pearson und die vollkommene Akzeptanz seiner Arbeitsmethoden betraf, eher eine Ausnahme unter den englischen Gefängnisärzten. ${ }^{68}$ Für Pearson wiederum verkörperte Goring das positive Beispiel eines Wissenschaftlers, der seine wissenschaftlichen Ambitionen nicht durch den Eintritt in den Staatsdienst aufgegeben hatte, sondern sich prinzipiell das Recht auf freie Forschung vorbehielt und für neue Erkenntnisse offen blieb: „Scientists may even take heart and recognise that the rule that the scientist ceases to be when he passes into government service has its occasional exceptions, and Goring was one of them. "69 Ähnlich wie Pearson repräsentierte Goring einen Wissenschaftlertypus, der sich stets auf seine vorurteilsfreien und sachlichen Forschungsverfahren berief, aus denen objektive, wertfreie Erkenntnisse hervorgingen. Was Wissenschaft leisten sollte, hatte Pearson 1891 bereits in seinen Gresham-Vorlesungen formuliert: „The classification of facts and the formation of absolute judgments upon the basis of this classification - judgements independent of the idiosyncrasies of the individual mind - essentially sum up the aim and method of modern science. "70 Der Wissenschaftler müsse sich dabei permanent

${ }^{65}$ Goring, English Convict, S. 27.

${ }^{66}$ Charles Goring, The Etiology of Crime, in: The Journal of Mental Science 64 (1918), S. 129 146, hier S. 135.

67 Ebd., S. 134.

${ }^{68}$ Vgl. Beirne, Heredity, S. 324, Anm. 12: der große Einfluss von Pearson auf Goring und die private Nähe und Freundschaft der beiden Männer lässt sich an der umfangreichen Korrespondenz zwischen Goring und Pearson verfolgen, die sich in den Pearson Papers (625) am University College in London befindet. Gorings Briefe begannen häufig mit „cher maitre“. Zwei Tage nach Gorings Tod unterrichtete dessen Frau Pearson und bat ihn, auf der Beerdigung eine Rede zu halten; ausführliche Nachrufe auf Goring erschienen in Biometrika; siehe auch BeIRne, Science, S. 198f.; DAVIES, Tracing the Criminal, S. $232 \mathrm{f}$.

${ }^{69}$ Pearson, Vorwort, S. xi.

70 Karl Pearson, The Grammar of Science (1892), 2. erweit. Aufl. London 1900, S. 6, Hervorhebungen im Original; das Buch war aus seinen Gresham-Vorlesungen am University College 1891 hervorgegangen. 
um eine Art ,Selbstauslöschung ${ }^{\text {(71 }}$ in seinen Urteilen bemühen, um Argumente anbieten zu können, die von jedermann sofort als wahr akzeptiert werden könnten. Da sich die Biologie durch das biometrische Verfahren der Mathematik annähere, könnten Fakten so präsentiert werden, ,that the reader's mind is irresistibly led to acknowledge a logical sequence - a law which appeals to the reason before it captivates the imagination. "72 Erkenntnisse wurden damit selbstevident, Deutungen und Interpretationen waren nur noch Beschreibungen sich von selbst aufdrängenden Wahrheiten.

Ähnlich wie Pearson ${ }^{73}$ schien auch Goring davon überzeugt zu sein, dass in den Schaltzentralen der Macht immer noch zu wenige saßen, die etwas von Wissenschaft verstanden und deshalb deren Stellenwert verkannten. Herbert Smalley, der Medical Inspector of Prison, firmierte in Gorings Briefen an Pearson als „that unenlightened gentleman", und seine persönliche Enttäuschung über die zurückhaltende Aufnahme von The English Convict durch die Prison Commission führte Goring auf „the reckless pretensions and native inefficiency, and cynical selfishness"74 dieses Gremiums zurück.

\subsection{Charles Gorings - The English Convict (1913)}

Die Stärke von Gorings Studie lag in ihrem wissenschaftlichen Anspruch und in der Offenlegung der angewandten Methoden. Das Einführungskapitel The Scientific Study of the Criminal enthielt in komprimierter Form das wissenschaftliche Credo der Biometriker: Einzig mit den Methoden der korrelativen Statistik, d.h. durch die mathematische Analyse großer, sorgfältig gesammelter Datenkonvolute, könnten wissenschaftlich verifizier- oder falsifizierbare Erkenntnisse über Kriminelle gewonnen werden. ${ }^{75}$ Dabei konstituierte das bloße Sammeln von Fakten, die Aufstellung ganzer Serien biologischer oder sozialer Daten, nach Auffassung der Biometriker noch kein Wissen. Ein wirklicher Erkenntnisgewinn sei nur durch die Entdeckung von Beziehungen zwischen einzelnen Faktensets möglich, bei denen es sich, das sollte eine ausreichend große Menge an Daten sicherstellen, nicht um zufällige, sondern real existierende Verbindungen zwischen natürlichen Phänomenen handelte. ${ }^{76}$ Statistik als nachvollziehbares mathematisches Verfahren sollte nicht nur diese Beziehungen nachweisen, sondern auch Aussagen über den Grad ihrer jeweiligen Ausprägung treffen.

Das hochkomplexe Untersuchungsobjekt Mensch stellte allerdings auch Biometriker vor besondere Herausforderungen: „The attributes and conditions of

${ }^{71}$ Ebd., S. 6; eine gute und knappe Zusammenfassung von The English Convict findet sich auch in BEIRNE, Science, S. 199-210.

72 Pearson, Grammar of Science, S. 10.

73 Siehe dazu ausführlicher Kap. 5.9.

74 Charles Goring an Karl Pearson (1912), zit. nach BeIRne, Heredity, S. 322, Anm. 9.

75 Goring, English Convict, S. 19.

76 Ebd. 
living things are so widely variable, are so delicately graduated in different individuals, that their correlation can seldom be legitimately postulated, and can never be precisely estimated, without aid from a correlation calculus. "77 Mit Hilfe von Integral- und Differentialrechnung ließen sich stets nur Annäherungswerte, Wahrscheinlichkeitsaussagen, aber nie absolute Bestimmungen über diese Beziehungen gewinnen. Trotzdem kam diesen Erkenntnissen ein ganz anderer Stellenwert zu als den bloßen Mutmaßungen selbsternannter Reformer über den Einfluss von Armut, Alkoholmissbrauch, Mangel an Bildung, elterlicher Vernachlässigung u.a.m. Wie sollte mit einiger Sicherheit festgestellt werden, in welcher Intensität sich solche Faktoren auf Individuen auswirkten? Alles, was man leisten könne, so erklärte Goring, „, is to measure, by the statistical method of averaging large numbers, the extent to which an increasing tendency to commit anti-social acts is correlated with different degrees or variations of the personal, economic, and social conditions under investigation." 78

Einzige Ausgangshypothese der Untersuchung war die Annahme, dass sich Kriminelle ,in ihrer Art' nicht von gesetzestreuen Durchschnittsbürger unterschieden, es sich also um normale menschliche Wesen handelte. Und weiter führt Goring aus: „that the criminal thing, whatever its nature may ultimately be shown to be, is not a pathological product, but is a physiological condition of the human mind; that whatever difference there may be underlying the acts of the law-breaker and those of the law-abiding person, the difference is one of degree only, and not of kind. "79 An keiner anderen Stelle wird so deutlich, wie hier die gewählte Untersuchungsmethode eine zentrale Grundannahme über das Untersuchungsobjekt voraussetzt. In der Biometrie konnten Kriminelle und kriminelle Handlungen nur als graduelle Abweichungen von einem statistisch ermittelten Durchschnitt erfasst werden. Der experimentellen Biologie und der Mutationstheorie dagegen lag durch die Annahme der Möglichkeit spontaner Neuschöpfungen von Arten in der Natur die Idee gänzlich neuer und andersartiger Arten viel näher. ${ }^{80}$

77 Ebd., S. 20.

78 Ebd., S. 20 f., Hervorhebung S.F.

79 Ebd., S.21, Hervorhebung S.F.; zit. auch in BeIRne, Science, S.200; Wissenschaftler wie Weldon und Pearson glaubten deshalb auch, dass sich die Biometrie hervorragend auf die Evolutionstheorie anwenden lasse, zumindest was die Berechnung der Rate und Richtung evolutionärer Prozesse betraf. Dies war ohne jegliches theoretisches Wissen über die Mechanismen der Vererbung möglich: „Knowing that a given deviation from the mean character is associated with a greater or lesser percentage death rate in the animals possessing it, the importance of such a deviation can be estimated without the necessity of inquiring how that increase or decrease in the death rate is brought about, so that all ideas of ,functional adaptation' become unnecessary." Weldon, An Attempt to measure the Death-Rate due to the Selective Destruction of Carcinus Moenas with Respect to a Particular Dimension, hier zit. nach BEIRNE, Science, S. 196.

80 Überlegungen zum ,Durchschnittstypen`im Gegensatz zu einem ,Idealtypen`, gegen den dann alle im Vergleich ,abfallen', gab es bereits früher. Besonders Weldon hatte in Anlehnung an Galton dafür plädiert: „Weldon suggested that rather than construct an ideal type of a species, as did anatomists, biologists could identify and focus on an actual average type and the extent and sort of variation from it." BEIRnE, Science, S. 196. 
Was aber war normal? Lombroso war diese Erklärung schuldig geblieben, doch es war unschwer zu erkennen, dass er einen Begriff von Normalität verwendet hatte, der eigentlich auch nur das statistische Mittel meinen konnte. ${ }^{81}$ Mit ihm operierte auch Goring. Aber im Gegensatz zu Lombroso ergab sich für Goring daraus eine andere Bestimmung von Abweichung. Was die Anthropologen als ,abnormal' bezeichneten und damit in eine pathologische Richtung verwiesen, sei doch nur ,anormal' ( unusual) im Sinne einer „rarity of existence“ 82 Gemessen am statistischen Mittel komme die Variation eines bestimmten Merkmals seltener vor und werde in seiner Erscheinungsform als ungewöhnlich wahrgenommen, weil sich Biometriker am Grundsatz orientierten:

Nature distributes her attributes in a continuous quantitative series; and any apparent difference of quality, in a normal series of people, will invariably be found, upon analysis, to consist ultimately in a difference of degree only. There is no line of demarcation, for instance, between good temper and bad temper, and no qualitative difference, as the verbal distinctions suggests; there is, rather, every degree of temper between an extreme serenity of good temper and an extreme violence of bad temper. ${ }^{83}$

Extreme Varianten eines Merkmals waren sehr selten, moderate graduelle Abweichungen dagegen häufiger anzutreffen. Aber alle Grade einer Abweichung hatten schließlich eines gemeinsam, sie waren „perfectly normal [...] in the sense that they are all perfectly natural". 84

Da Goring aufgrund der von ihm gewählten Methode die gänzliche Andersartigkeit von Merkmalen ablehnte, fand er die zeitgenössischen Bezeichnungen bestimmter Bevölkerungsgruppen als „mentally defective type“, „degenerate type“, und „criminal type “85 gefährlich und wissenschaftlich höchst fragwürdig, denn sie suggerierten, dass es sich bei diesen Gruppen um abnorme, also um manifest krankhafte, d.h. andersartige und nicht bloß um ungewöhnliche Gruppen handelte. ${ }^{86}$ Menschen wurde eine angeborene Störung ihrer Gehirnfunktionen unterstellt und das damit in Verbindung gebrachte Fehlverhalten nicht mehr als Abweichung vom normalen Durchschnitt, sondern als Resultat des angeborenen Defekts interpretiert. Das Einzige, was man nach Gorings Auffassung legitimer Weise behaupten durfte, war, dass diese Menschen von „objectionable or dangerous de-

81 So schätzt es auch BeIrne, Science, S. 201, ein. Karl Pearson, Gorings Lehrer, wird es in der 2. Auflage so zusammenfassen: „The criminal is not a random sample of the general population, either physically or mentally. He is rather a sample of the less fit moiety of it." KARL Pearson, Charles Goring and his Contributions to Criminology, in: Charles Goring, The English Convict. A Statistical Study, London 1919, S. ix.

82 Ebd., S. 22.

83 Ebd., Hervorhebung im Original.

84 Ebd.

85 Ebd., S. 24.

${ }^{86}$ Vgl. ebd., S.23; interessanter Weise stellte Goring die Existenz abnormer, pathologischer Krankheitszustände nicht in Frage, es gab zweifellos Krankheitsbilder, die gänzlich von einem normalen Zustand unterschieden waren. Aber ein normaler Zustand ging nicht in graduellen Schritten in einen abnormen Zustand über, sondern dieser Übergang war sprunghaft, abrupt, ein Zustand war durch eine scharfe Demarkationslinie vom anderen getrennt und als ein solcher auch erkennbar und diagnostizierbar. Bei Krankheiten akzeptierte Goring scheinbar doch Mutationstheorien. 
grees of qualities“ gekennzeichnet waren, „, which, in some degree, are possessed by the whole human race" 87

Gorings Kritik erinnerte daran, dass in der Zuschreibung von Abnormität eine falsche bzw. nicht überprüfbare Theorie zum Tragen kam. Es war ein direkter Angriff auf jene Experimentalbiologen, die die Mendelsche Vererbungslehre und bestimmte Mutationstheorien auch bei der Vererbung komplexer menschlicher Eigenschaften als unit characters zugrunde legten:

The theory of the existence of these specific morbid types is founded wholly upon the prejudice which assumes that all human qualities showing a marked deviation from the average are spontaneous germinal variations and indications of mental defect or disease. In short, the theory in question is an unverified hypothesis, based entirely upon the assumed legitimacy of a very questionable inference. ${ }^{88}$

Nach Gorings Auffassung hatten es Männer wie Bateson und Davenport vermocht, Alltagsglauben zu bestätigen, indem sie unrechtmäßig, weil nur hypothetisch, die Entstehung von Abweichungen in Aussehen und Verhalten von Kriminellen auf eine - bislang noch nicht bewiesene - Spontanmutation der Keimzellen zurückführten. ${ }^{89}$ Man könne durchaus zugeben, dass der Kriminelle viele der behaupteten Eigenschaften besitze, dass er oft wie ein ,Raubvogel' aussehe oder eine bestimmte Kopfform aufweise, dass er betrunken, impulsiv, widerspenstig, schmutzig und ohne Kontrolle auftrete. Und dennoch: eines sei dadurch noch nicht bewiesen, dass er ein qualitativ gänzlich anders strukturiertes, abnormes Wesen sei. „He may represent a selected class of normal man; many of his qualities may present extreme degrees from the normal average: yet the fact remains that $[\ldots]$ he exists by the same nature [...] of normal human beings. "90

Bis zu diesen Ausführungen konnten sich die Mitglieder der Prison Commission noch problemlos mit Gorings kritischen Einwänden einverstanden erklären. Gegen den Hinweis auf die Normalität des Kriminellen und die Wissenschaftlichkeit statistischer Methoden wollten sie gewiss nichts einwenden. Die Konzentration auf Kriminalität als Abweichung von einem normalen Mittel konzipierte den Straftäter zunächst einmal nur als ,ungewöhnliche' Variante der Gattung Mensch. Doch Goring, der den geborenen kriminellen Typus Lombrososcher Prägung gerade verabschiedet hatte, holte den abnormen Kriminellen durch einen Akt der ,Resubstantivierung' wieder in die Diskussion zurück. Kritischen Zeitgenossen sollte diese neue, anders begründete physiologische Kriminologie nicht verborgen bleiben. Sie löste nicht nur in der staatlichen Verwaltung Unbehagen aus, sie führte auch zu heftiger Kritik in der Öffentlichkeit. ${ }^{91}$

87 GorING, English Convict, S. 24, Hervorhebung S.F.

$88 \mathrm{Ebd}$.

${ }^{89}$ Vgl. ebd., S. 27: „We owe much to the experimental methods of investigating natural phenomena in plants and animals, but, in the future, our debt will be as great to the statistical method which has already begun to throw light upon the many hitherto obscure phenomena related to the lives and conditions of human beings."

90 Ebd., S. $24 \mathrm{f}$.

91 Siehe dazu ausführlicher Kap. 5.7. und Kap.5.9.; auch WIENER, Reconstructing, S. 357. 


\section{Criminal diathesis}

Das Prinzip, dass es sich beim Kriminellen um ein normales menschliches Wesen handelte, bedurfte keiner besonderen Theorie. Dennoch benötigte Goring für die Erarbeitung eines erklärenden Kriminalitätskonzepts eine Arbeitshypothese, eine vorläufige Hypothese über die Natur der mentalen und moralischen Identität des verurteilten Straftäters. Unzulässig war, wie er selbst ja ausgeführt hatte, aufgrund der komplizierten Beschaffenheit des menschlichen Geistes und der Veränderbarkeit und Komplexität von Umwelteinflüssen a priori zu behaupten, der Kriminelle sei geboren oder eben ,gemacht'. Alles, was man annehmen durfte und in der Tat annehmen musste, war die Möglichkeit, dass sowohl Anlage- als auch Umwelteinflüsse eine Rolle in der Genese von Kriminalität spielten. Daran war nichts auszusetzen. Doch durch die folgende Definition konzeptualisierte Goring das Wechselspiel dieser Faktoren zu einer neuen, wenn auch zunächst nur hypothetischen kriminellen Entität: „we are forced to an hypothesis of the possible existence of a character in all men which, in the absence of a better term, we call the ,criminal diathesis. "92 Das Wort criminal sollte dabei nichts anderes implizieren als die Tatsache, dass ein Individuum zu einer Gefängnisstrafe verurteilt worden war, während der Begriff diathesis nach Gorings eigenen Worten „a hypothetical character of some kind“ implizierte, „a constitutional proclivity, either mental, moral or physical, present to a certain degree in all individuals, but so potent, as to determine for them, eventually, the fate of imprisonment. "93 Eine direkte Quantifizierung der criminal diathesis war unmöglich, da sich ihre Wahrnehmung den Sinnen entzog. Man konnte ihr nur auf dem Weg der quantifizierten Kriminalität selbst auf die Spur kommen.

Gorings „constitutional proclivity "94 war aber mehr als eine bloße Disposition oder Tendenz, die den Kriminellen in besonderer Weise auszeichnete. Sie war ein manifest gewordenes Produkt aus dem Zusammenspiel von Umwelteinflüssen und konstitutioneller Beschaffenheit, das das Handeln derjenigen Individuen bestimmte, bei denen diese criminal diathesis über den Durchschnitt hinaus besonders stark ausgeprägt war. Es sollte sich bald herausstellen, dass Goring im Grunde den anthropologischen Typus mit erkennbar physischen Eigenschaften durch einen kriminellen Typus ersetzte, der durch mentale Defekte und intellektuelle Defizite gekennzeichnet war, die aber als nicht weniger manifest angenommen wurden. ${ }^{95}$ Goring gab das sogar offen zu: „We do not see how the conclusion can be evaded that the criminal diathesis [...] is a certain constitutional fact." ${ }^{\text {"96 }}$

\footnotetext{
92 Goring, English Convict, S. 26; vgl. dazu auch BeIRne, Science, S. 201.

93 Ebd., S. 26, Hervorhebung S.F.

94 Ebd.

95 Siehe ebd., Anm. auf S. 26:, In every branch of our investigation we shall be compelled to assume the possible existence of this so-called „criminal diathesis“; that is to say, we shall have to pursue our research with a mind open to the possibility that innate or constitutional, as well as environmental factors, play a part in determining the fate of the criminal."

96 Ebd., S. 27.
} 
In seiner Einleitung blieb Goring eine genauere Bestimmungen derjenigen Qualitäten, die diese criminal diathesis ausmachten, schuldig. Allen Straffälligen glaubte er sie ohne Mühe zuschreiben zu können, obgleich auch nichts dagegen sprach, dass sie in jedem gesetzestreuen Bürger anzutreffen war, wenn auch eben nicht in einer so signifikanten Ausprägung. ${ }^{97}$ Mit der Einführung des Konzepts einer criminal diathesis war die Richtung der Untersuchung vorgegeben: Es ging nun um die Frage, inwieweit diese criminal diathesis, „as measured by criminal records, is associated with environment, training, stock, and with the physical attributes of the criminal. "98 Entsprechend beschäftigte sich die Untersuchung mit der physischen Erscheinung von Kriminellen, dem biologischen Alter als ätiologischem Faktor, mit Daten der Bevölkerungsstatistik (Gesundheit, Krankheit, Sterblichkeit, prozentualer Anteil von Straffälligen an der Gesamtbevölkerung u.a.m.), mit den mentalen Abweichungen von Kriminellen, dem Einfluss bestimmter Umweltfaktoren auf das Entstehen von Kriminalität, der Fruchtbarkeit von Kriminellen und schließlich mit Vererbungsfaktoren.

\section{Ergebnisse}

Wie von vielen antizipiert, bestätigte Gorings Studie auf eindruckvolle Weise: "[N]o evidence has emerged confirming the existence of a physical type, such as Lombroso and his disciples have described-our inevitable conclusion must be that there is no such thing as a physical criminal type."99 Unter Hinzuziehung von Datenmaterial des Central Metric Office von New Scotland Yard, ${ }^{100}$ das Gewohnheitsverbrecher registrierte und ihre Identifikationsmerkmale katalogisierte, ergab der Vergleich zwischen verschiedenen kriminellen Gruppen (Diebe, Sexualverbrecher, Betrüger u.a.) untereinander und der Vergleich zwischen der kriminellen Klasse und der Klasse gesetzestreuer Personen (Studenten, Royal Engineers, Undergraduates aus Oxford, Mitarbeiter des biometrischen Labors) nur, dass sowohl innerhalb der kriminellen Gruppe als auch innerhalb der Kontrollgruppe eine große Variation an physischen Merkmalen existierte. ${ }^{101}$ Dieses Ergebnis war allerdings zum Zeitpunkt seiner Veröffentlichung keine großartige Erkenntnis mehr, denn nicht zuletzt Lombroso selbst hatte aufgrund der zahlreichen Kritik vor allem von Seiten französischer Kriminologen an seinem ursprünglichen Konzept des ,geborenen Verbrechers' in den folgenden Auflagen seines Werkes immer mehr Zugeständnisse und Einschränkungen gemacht. Dies schien Goring aber entgangen zu sein. ${ }^{102}$

97 Ebd.

98 Ebd.

99 Ebd., S. 173, Hervorhebung im Original; siehe auch BEIRNE, Science, S. 203.

100 Vgl. ebd., S. 140.

101 Ebd., S. 173.

102 Zur französischen Kritik und Gorings mangelnder bzw. fehlender Rezeption dieser Kritik siehe BeIRne, Science, S.211f.; er führt diesen Mangel auf Gorings Lombroso-Rezeption über englische Sekundärliteratur zurück. 
Alle weiteren Erkenntnisse in Gorings Studie waren weitaus ambivalenter und schwieriger $\mathrm{zu}$ interpretieren. So ergab sich deutlich, dass die kriminelle Klasse insgesamt eine schlechtere physische Konstitution - sie waren leichter und kleiner - aufwies als die gesetzestreue Vergleichsgruppe. ${ }^{103}$ Innerhalb der kriminellen Gruppe kam die körperliche Verfassung der Betrüger, also Straftäter, denen ein gewisses Maß an Intelligenz unterstellt werden konnte, der körperlichen Verfassung der gesetzestreuen Vergleichsgruppe noch am nächsten. ${ }^{104}$ Dass Goring einer neuen physiologischen Interpretation von Kriminalität zuneigte, offenbarte sich bereits hier durch seine Interpretation des Sachverhalts. Statt, wie es die British Association mit einer ähnlichen Untersuchung der normalen Bevölkerung getan hatte, diese körperliche Unterlegenheit auf die ungünstigeren Lebensbedingungen (z. B. Mangelernährung) der unteren Klassen zurückzuführen, ${ }^{105}$ favorisierte Goring einen negativen Selektionsprozess als Erklärung. ${ }^{106}$ Gemeint war damit, dass eine gute physische Verfassung auf dem Arbeitsmarkt Vorteile verschaffte und all jene das Nachsehen hatten, die damit nicht ausgestattet waren. Durch ihre körperliche und geistige Unterlegenheit zeigten sie dann eine größere Bereitschaft zu kriminellem Handeln. Generell hielt sich Goring aber die Möglichkeit offen, dass diese physische Inferiorität zu einer manifesten Eigenschaft innerhalb der kriminellen Gruppe werden konnte: „Physical inferiority, originating in and fostered by selection, may tend with time to become an inbred characteristic of the criminal classes." 107 Die Schlussfolgerung konnte dann nicht überraschen: „Our final conclusion is that criminal anthropology is not entirely without basis in fact." 108

Bezogen auf die soziale Verteilung geistiger Fähigkeiten (z. B. Intelligenz) sah Gorings Ergebnis ähnlich aus. Während die Royal Commission of the Care and Control of the Feeble-minded in ihren Untersuchungen zu dem Ergebnis gekommen war, dass $1 \%$ der Bevölkerung als ,mentally defective ' eingestuft werden mussten, ermittelte Goring einen Prozentsatz von 10 bis $20 \%$ für die gleiche Gruppe innerhalb der Gefängnispopulation. ${ }^{109}$ Da keine Intelligenztests durchgeführt wurden, beruhte diese Einschätzung alleine auf der des untersuchenden und die Daten aufnehmenden Arztes. Goring betonte auch hier den selektiven Prozess durch den offensichtlichen Zusammenhang von mentalen Defiziten und kriminellen Karrieren. ${ }^{110}$ Die hohe Korrelation $(\mathrm{r}=0.64)$ von defekter Intelligenz und Kriminalität war schließlich auch ein Grund, warum die geistig Schwächsten am häufigsten im Gefängnis landeten: „the abler would more skillfully evade, and

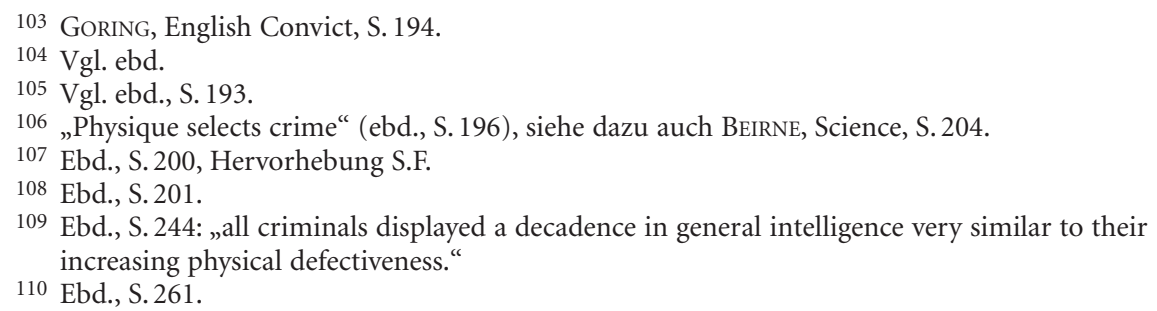


the mentally defective would more inevitably become entangled in the meshes of the police net." 111 Goring ging sogar soweit, dass er in dieser mentalen ,defectiveness' den wohl wichtigsten Faktor in der Genese von Kriminalität überhaupt sah und in ihr auch die Voraussetzung für Pathologien wie Alkoholismus, Epilepsie und Geisteskrankheit vermutete. ${ }^{112}$

\section{Umwelt}

Gorings Untersuchung von Umwelteinflüssen auf die Genese von Kriminalität war einer der wichtigsten Abschnitte des Buches. Die erwarteten Einwände von Sozialreformern und Philanthropen antizipierend stellte er diesem Kapitel eine längere Einführung voran, in der er sich mit dem seiner Meinung nach falschen Vorgehen der ,Soziologen' auseinandersetzte. ${ }^{113}$ Ihnen warf er vor, dass sie die bloße Aufzählung der Bedingungen, die allgemein mit Kriminalität in Verbindung gebracht wurden, bereits als ausreichende ,echte' Gründe für die Genese von Kriminalität betrachteten. Was sie als Ursache bezeichneten, war aber möglicherweise nur "the mere co-existence of associated phenomena". 114 Goring war nicht klar, wie sich Ursachen ohne die Analyse von Beziehungen mithilfe statistischer Methoden ${ }^{115}$ überhaupt wissenschaftlich ergründen ließen. Das Vorgehen der Soziologen und Sozialreformer war in seinen Augen jedenfalls nur eine intuitive, introspektive und deskriptive Untersuchungsmethode. ${ }^{116}$ Gorings Einwände waren keine reine Polemik, denn vom wissenschaftlichen Standpunkt aus war sein Hinweis sicher richtig, dass es zwischen sozialen Phänomenen nie so etwas wie absolute Kausalität geben konnte: „[T]hese can only be described as related to each other by a graduated bond of association, whose strength may range from the zero of mere chance concomitance, up to degrees approximating in intensity to, but never reaching, the physicist's definition of absolute causation." ${ }^{117}$ Alles, was wissenschaftlich möglich sei, sei mithin die Entdeckung und Katalogisierung der Ursachen in der Reihenfolge ihrer Potenz, ${ }^{118}$ die Festlegung der relativen Intensität von verschiedenen Umwelteinflüssen auf die Genese von Kriminalität.

Trotz dieses logisch starken Argumentes ist es an dieser Stelle wiederum auffällig, dass Goring hier - ähnlich wie es Leonard Darwin in seinem Vortrag über den Gewohnheitsverbrecher ein Jahr später tun wird - selbst einschränkende Bemer-

111 Ebd., 262.

112 Ebd.

113 Beirne macht darauf aufmerksam, dass Goring scheinbar keine Kenntnisse über französische Soziologen wie Emil Durkheim und Gabriel Tarde besaß (siehe BeIRNE, Heredity, S.332), statt dessen setzte er sich mit dem amerikanischen Gefängnisreformer Frederick Howard Wines (Punishment and Reformation) auseinander, siehe GORING, English Convict, S. 263.

114 Ebd., S. 264.

115 Ebd., S. 264.

116 Ebd.

117 Ebd., S. 265.

118 Ebd. 
kungen zu den Möglichkeiten statistischer Aussagen einfließen ließ: Mit Hilfe statistischer Verfahren konnten weder Aussagen über die Richtung des Einflusses (wer oder was wirkt auf wen oder was) noch über seine genaue Beschaffenheit (wie und auf welche Weise wirkt er) eines bestimmten Faktors gemacht werden. ${ }^{119}$ Umwelteinflüssen, die möglicherweise mit der Genese von Kriminalität in Verbindung gebracht werden konnten, waren so vielfältig und kompliziert, ,and may come into association in so great a variety of ways and degrees, that to disentangle satisfactorily the contributory effectiveness of each from, and in relation to all others, would lead to a long and complicated inquiry. "120 Auch Goring vermochte dies in der vorliegenden Studie nicht zu leisten und versprach stattdessen nur einen groben, vorläufigen und möglicherweise oberflächlichen Überblick. Erschwerend kam hinzu, dass die verfügbaren Daten ausschließlich aus der Gruppe der Schwerverbrecher (convicts) gewonnen worden waren und damit einen möglicherweise nicht repräsentativen Ausschnitt darstellten, da es sich vor allem um viele Gewohnheitsverbrecher mit hoher Rückfallquote handelte. Genau diese Rückfallquoten und verschiedene Verbrechertypen waren es dann aber, die Goring mit diversen äußeren Einflussfaktoren wie Nationalität, Arbeitsverhältnissen, Erziehung und Ausbildung, Familienleben und sozialer Zugehörigkeit korrelierte. All die von ihm selbst angeführten einschränkenden Bemerkungen hinderten ihn nicht daran, sehr eindeutige Ergebnisse zu bestimmten Einzelfragen vorzulegen:

Erstens: Für Politiker, die 1905 gerade den Aliens Act verabschiedet hatten, der u. a. die Ausweisung straffällig gewordener Ausländer vorsah, ${ }^{121}$ war Gorings Einzelergebnis von Interesse, dass z. B. Nationalität (Englishmen, Irishmen, foreigners, and Jews) beim Grad der Rückfälligkeit offensichtlich keine besondere Rolle spielte. ${ }^{122}$ Edward Troup, Permanent Under-Secretary im Home Office, und William Byrne vom Board of Control beschäftigten sich in einem Home Office Memorandum ausführlich mit diesem Punkt, wobei ihnen nicht klar war, warum in Gorings Studie "Jews" als gesonderte Nationalität aufgeführt worden war. ${ }^{123}$ Ansonsten glaubten sie Gorings Prozentsatz von in England begangenen Straftaten durch Ausländer als zu hoch angesetzt und bevorzugten Zahlen der eigenen Statistiken. ${ }^{124}$

Zweitens: Während Gorings Ergebnisse in Bezug auf Arbeitsverhältnisse, die u. a. besagten, dass mit Arbeitslosen die höchsten Rückfallquoten und längsten Gefängnisstrafen verbunden waren, ${ }^{125}$ niemanden überraschten, mussten seine

119 Ebd., S. 266.

120 Ebd.

121 Tatsächlich sind einige straffällig gewordene Ausländer aufgrund dieses Gesetzes aus Großbritannien ausgewiesen worden, siehe dazu Christiane ReINEKe, Grenzen der Freizügigkeit. Die Politik der Migrationskontrolle in Großbritannien und Deutschland 1880-1930, München 2010; für diesen Hinweis danke ich Andreas Fahrmeir.

122 Goring, English Convict, S. 273.

123 Home Office Memorandum relating to the book, The English Convict' (5. November 1913), und Reply of Dr. Charles Goring, eingegangen 17. März 1914, beide Dokumente in TNA, HO 45/10563/172511.

124 Ebd.

125 Vgl. GorIng, English Convict, S. 274. 
Ergebnisse über den Einfluss von Bildung und Erziehung besonders Pädagogen und Philanthropen aufhorchen lassen: Weder die Art der Schulerziehung noch das Alter, mit dem die untersuchten Straftäter die Schule verlassen hatten, hatten irgendeinen nachweislichen Einfluss auf die kriminelle Karriere der Straftäter. ${ }^{126}$ Goring sprach der Schulerziehung jeglichen Einfluss ab. ${ }^{127}$

Drittens: In Bezug auf die Geschwisterreihenfolge, in die Straffällige hineingeboren wurden, ließ sich eine erhöhte Neigung zu antisozialem und kriminellen Verhalten bei erst- und zweitgeborenen Mitgliedern der Familie ausmachen. ${ }^{128}$ Da sich hier aber eine auffällige Parallele zu Erkrankungen wie Tuberkulose und Geisteskrankheit (insanity) zeigte, lag es für Goring nahe, diesem Befund konstitutionelle Ursachen zugrunde zu legen und keine von außen wirkenden Familieneinflüsse, die sich auf alle Kinder annähernd gleich hätten auswirken müssen: „[T] he special incidence of these states in the earlier born can only be due to the fact that the taints of tuberculosis and insanity are inherited in greater intensity by older than by younger members of a family. We would, accordingly, be inclined to attribute the increased tendency of elder members to be criminally convicted to their possessing, in some way, an increased intensity of constitutional criminal taint." 129 Hier zog Goring also, entgegen seinen eingangs gemachten Bemerkungen, doch ein pathologisches, somatisch-manifestes Beispiel heran, zudem ein fragliches, um mit dessen Hilfe die Ergebnisse in eine bestimmte Richtung zu interpretieren.

Viertens: Auch die Ergebnisse zum Verhältnis von Armut und Rückfälligkeit sind interessant. Die relative ökonomische Prosperität der Familie, in der der untersuchte Straftäter aufgewachsen war, hatte anscheinend keinen Einfluss auf die Frequenz seiner nachfolgenden Verurteilungen; gemessen an der Straflänge schien es sogar so, dass Armut mit Sicherheit nicht die Tendenz zur Rückfälligkeit ansteigen ließ, sondern im Gegenteil auf ihre Verringerung wirkte. ${ }^{130}$ Dieses Ergebnis war ein großer Affront gegen all jene sozialreformerischen Kräfte, deren Reformziele sich vor allem auf die materielle Verbesserung der unteren Klassen richteten. Die Hebung des Lebensstandards wurde von ihnen stets auch mit dem Verweis auf die Beseitigung oder Verhinderung krimineller Karrieren verteidigt.

Fünftens: Mit Blick auf den mütterlichen Einfluss - dies wird für die aufkommende Psychoanalyse von großer Bedeutung sein ${ }^{131}$ - korrelierte Goring den Zeitpunkt, an dem die Mutter des Straftäters gestorben war, mit dessen Rückfallhäufigkeit. Auch hier ergab sich keine signifikante Beziehung zwischen dem Tod der Mutter und dem Alter des Straftäters, d.h. ob er zu diesem Zeitpunkt noch ein Kind oder bereits ein Erwachsener gewesen war. Der Tod der Mutter wurde

126 Ebd., S. 275.

127 Ebd., S. 276.

128 Vgl. ebd., S. 279.

129 Ebd., S. 280, Hervorhebung S.F.

130 Vgl. ebd., S. 285.

131 Tatsächlich wird die Arbeit von John Bowlby in den 1940er Jahren genau das Gegenteil behaupten, vgl. dazu Kap. 6.14. 
folglich von Goring nur als ein „environmental accident without any significant relation to their [the convicts', S.F.] subsequent degree of recidivism"132 interpretiert.

Bei allen diesen Bezügen fiel nach Gorings Dafürhalten die verminderte Intelligenz des Straftäters, eine konstitutionelle Eigenschaft, am stärksten ins Gewicht. In ihr müsse ein „antecedent to his environmental misfortune“133 gesehen werden. Angesichts seiner Ergebnisse lautete Gorings abschließende Feststellung: „[R]elatively to its origin in the constitution of the malefactor, and especially in his mentally defective constitution, crime in this country is only to a trifling extent (if to any) the product of social inequality, of adverse environment, or of other manifestations of what may be comprehensively termed, the force of circumstances"“"134

\section{Anlage}

Nach seiner Absage an die Wichtigkeit von Umweltfaktoren für die Kriminalitätsgenese konzentrierte sich Goring in seinem abschließenden Kapitel ganz auf den Einfluss von Anlagefaktoren. Einmal mehr - und hier besonders deutlich - sprach aus den Zeilen der Kampf um die legitime Deutungshoheit der Biometriker in ihrer Auseinandersetzung mit den Experimentalbiologen bzw. Mendelianern. Dreh- und Angelpunkt bildeten der Begriff heredity und die Frage, wie über sie gesicherte Aussagen gemacht werden konnten. Wie Pearson war sich Goring darüber im Klaren, dass der Interpretation des biologischen Vererbungsmechanismus weitreichende Bedeutung in sozialen und ökonomischen Fragen zukam. ${ }^{135}$ Für Goring stand außer Frage, dass ein solcher Mechanismus existierte, - ein "germinal influence of some kind, which not only determines the generating of living organisms, but controls their persistent resemblance to an ancestral type“. Bislang konnte aber noch kein Gesetz menschlicher Vererbung formuliert werden. Ein aus der Vorstellungskraft abgeleitetes Gesetz könne niemals Licht in das Dunkel dieser Vorgänge bringen, dies könne allein aus Erfahrung geschehen, allerdings keiner biologischen, sondern einer statistischen Erfahrung. ${ }^{136}$

132 Goring, English Convict, S. 282.

133 Ebd., S. 287.

134 Ebd., S. 288, Hervorhebung S.F.

135 Ebd., S. 337, Hervorhebung im Original.

136 Ebd.; vgl. dazu auch GorING, Etiology of Crime, S. 138f.: „But what do separate by a sharp dividing line the doctrine of Biometricians from that of their more ambitious, but perhaps rather more confused, confréres, the Mendelians? It is this: that Biometricians refuse, and always have refused, to recognise any real existence in the unit characters, unit compartments, and sharply portioned pigeon-holes which are at the basis of Mendelian theory. The characteristic feature of Biometric doctrine is that nature distributes her attributes in continuous quantitative series. The tall and the short peas of Mendelians are not, according to Biometric teaching, specific entities of one definite degree: there is a wide range of tallness in the one variety, as there is a wide range of shortness in the other." 
Wenn Vererbung die Bestimmung der Intensität familiärer Ähnlichkeiten war, dann ging es in ihrer wissenschaftlichen Aufklärung um die Angabe von Verhältnissen. ${ }^{137}$ Goring demonstrierte die Vererbung der von ihm eingeführten criminal diathesis als statistisch berechenbare Größe im Verhältnis des Straftäters zu verschiedenen Familienkonstellationen: krimineller Vater, kriminelle Mutter, kriminelle Eltern und nicht kriminelle Eltern. Das Ergebnis schien eindeutig: ,the percentage of criminal offspring increases progressively according to whether neither parents, the mother only, the father only, or both parents, are criminal." 138 Dem Vater sprach Goring eine größere Vererbungspotenz als der Mutter zu, da im Falle nur eines kriminellen Elternteils die Zahlen der straffälligen Kinder bei einem kriminellen Vater höher lagen als bei einer straffälligen Mutter. Die Tatsache, dass es auch Straftäter gab, die keine kriminellen Eltern aufwiesen (immerhin 47\%), verleitete Goring zu einer weiteren interessanten Annahme: „the fact that many apparently law-abiding people are, what we would call, eventual criminals. They have inherited a certain grade of criminal diathesis; and although not to-day so designated, they will ultimately pass into the ranks of recognised criminals."139 Langfristig ließ sich einer erblichen Disposition also nicht entkommen.

Gegen Ende seiner Studie steuerte Goring schließlich nahezu vollständig auf eine physiologische Kriminologie zu. Dies wurde durch seine Interpretation des Heiratseinflusses auf die Genese von Kriminalität besonders deutlich. Seine Zahlen legten nahe, dass der Einfluss - wohlgemerkt durch vererbte Disposition, nicht durch soziale Kontaminierung - eines kriminellen Ehepartners als ähnlich stark angenommen werden müsste wie der Einfluss von kriminellen Eltern oder Brüdern, obgleich beim Eheverhältnis keine Blutsverwandtschaft vorlag. Zur Erklärung ließ Goring die soziale Kontaminierung ganz außer Acht und kombinierte statt dessen seine Selektionstheorie mit der Vorstellung einer , anlagebedingten Wahlverwandtschaft', nämlich „certain selective influence in marriage, known as the influence of ,assortive mating', by which individuals do not mate at random, but tend rather to intermarry with their own kind." 140

Zwei Aussagen fassten abschließend die zentralen Ergebnisse zusammen:

$[\mathrm{O}]$ ne is that the criminal diathesis, revealed by the tendency to be convicted and imprisoned for crime, is inherited at much the same rate as are other physical and mental qualities and pathological conditions in man. The second is that the influence of parental contagion $[=$ environment, S.F.], although varying somewhat in intensity in different conditions, is, on the whole, inconsiderable, relatively to the influence of inheritance, and of mental defectiveness: which are by far the most significant factors we have been able to discover in the etiology of crime. ${ }^{141}$

137 Vgl. Goring, Etiology of Crime, S. 140, S. 145: „[A]s we modify one variable, what is the observed effect on another variable?"

138 Ebd., S. 348 .

139 Ebd., S. 348, Hervorhebung S.F.

140 Goring, English Convict, S. 366.

141 Ebd., S. 368, Hervorhebung S.F. 


\section{Eugenische Empfehlungen}

Wie Pearson wusste auch Goring, dass der Erkenntnis und Interpretation der Vererbungsmechanismen weitreichende soziale und politische Bedeutung zukamen. Bereits 1892 hatte Pearson in seinen öffentlichen Gresham-Vorlesungen diese Tatsache betont: „The laws of heredity, whatever they may be, must profoundly influence our judgment. The conduct of parent to child, and of society to its antisocial members, can never be placed on sound and permanent bases without regard be paid to what science has to tell us on the fundamental problems of inheritance." 142 Die letzten Seiten der Studie nutzte Goring ganz in diesem Sinne zu einem Appell an die politischen Entscheidungsträger, die biometrische Statistik als seriöse Methode in politische Entscheidungsprozesse einzubinden: „to obtain the truth, our appeal must be made, not to the opinions of descriptive psychologists, sociologists, and criminologists, but to the facts and calculus of the statistician." 143 Vererbung sei kein Feind, den man fürchten müsse, so erklärte Goring, sondern eine universelle und natürliche Kraft, die studiert und aufgeklärt werden müsse, um sie bewusst zum Wohle der Menschheit einzusetzen. ${ }^{144}$ Einige seiner Empfehlungen entsprachen denen der Eugenischen Gesellschaft. ${ }^{145}$ So empfahl Goring u.a. die Gelegenheit zu kriminellen Handlungen durch die „segregation and supervision of the unfit“ zu reduzieren, und „to regulate the reproduction of those degrees of constitutional qualities - feeble-mindedness, inebriety, epilepsy, deficient social instinct, etc. - which conduce to the committing of crime." ${ }^{146}$

\section{6. "More Lombrosian than Lombroso": Gorings Befünvorter}

Gorings Hinwendung zu einer neuen, wissenschaftlich fundierten Form positivistischer Kriminologie und nicht zuletzt seine eugenischen Empfehlungen brachten ihm die Bewunderung und Anerkennung all jener ein, die sich durch seine Studie in ihrer eigenen Arbeit bestätigt fühlten: Mitglieder der Eugenics Education Society, die Italienische Schule und das biometrische Labor. Leonard Darwin, Präsident der Eugenics Education Society, wies 1914 auf Gorings Ergebnisse in seiner

142 Pearson, Grammar of Science, S. 27f., Hervorhebung S.F.

143 Goring, English Convict, S. 374.

144 Ebd., S.373.

145 Piers Beirne hat nachgerechnet, dass Zweidrittel aller in The English Convict aufgeführten wissenschaftlichen Titel aus der britischen biometrischen oder eugenischen Literatur stammen. Es handelte sich entweder um die Publikationen des Galton Eugenics Institute und schloss die Arbeiten von Francis Galton und Karl Pearson mit ein, oder es handelte sich um die populistische, bekehrende Literatur der Eugenics Education Society, also Beiträge aus der Eugenics Review. BeIRne, Science, S. 207.

146 Goring, English Convict, S. 373. 
Präsidentenansprache hin und betonte, dass solche „innate qualities exceptionally well marked in criminals “147 nun als erblich nachgewiesen worden seien.

Auch die Anhänger die Italienischen Schule, Enrico Ferri, Sante De Sanctis und Lombrosos Tochter, Gina Lombroso-Ferrero, sahen in Gorings Studie, selbst noch in der Anordnung seiner Tabellen und ihrer Interpretation, eine „homage "148 an die Arbeit des italienischen Kriminalanthropologen, obgleich sie kritisierten, dass ihre eigenen Studien von Goring ganz offensichtlich ignoriert worden seien: ${ }^{149}$ „Even if he had proved that some of our anthropological figures were wrong, or erroneous,“ schrieb Gina Lombroso-Ferrero, „I would not hesitate to declare that this work is altogether the most important document of criminal anthropology which has appeared during the last years in support of the new school." ${ }^{150}$ Gina Lombroso-Ferrero betonte, dass die ganze Untersuchung ja keineswegs von Freunden ihres Vaters angeregt worden sei, sondern von seinen Gegnern. Umso erstaunlicher sei das beeindruckende Ergebnis, dessen Vorstellung dann ausführlich folgt.

Gorings Beharren auf eine überwiegend biologisch determinierte Disposition des Kriminellen, die Betonung der Erbfaktoren und die in seinen Augen absolut marginale Bedeutung von Umwelteinflüssen veranlassten die italienischen Kriminologen zu der Bemerkung, dass Goring ganz offensichtlich „more Lombrosian than Lombroso"151 sei, denn auch die Italienische Schule war inzwischen dazu übergegangen, dem Einfluss äußerer Einflüsse in ihren Untersuchungen zunehmend Rechnung zu tragen. Nicht zuletzt Lombroso selbst hatte als Reaktion auf die vielfältige Kritik immer stärker solche Faktoren berücksichtigt, was allein das Anwachsen des Umfangs seines Buches auf 2000 Seiten in den späten Auflagen deutlich macht. ${ }^{152}$

147 Siehe dazu Darwin, Habitual Criminal, S. 207; zur Diskussion dieses Punktes siehe auch GARLAND, Punishment and Welfare, S. 184-185; auch DarWIN, Eugenic Reform, S. 208-211.

148 SANTE De Sanctis, Una Inchiesta sui condannati inglesi e l'Antropologia criminale, in: La Scuola Positiva (März 1914), hier zit. nach The Penal Reformer 6 (1914), S. 13; ebenso auch EnRICo FerRI, L'Attuale Momento Dell'Antropologia Criminale, in: La Scuola Positiva (November 1913).

149 Zur Auseinandersetzung mit Gorings Studie durch die Italienische Schule siehe die Beiträge $\mathrm{zu}$ „The English Convict: A Symposium“: GINA Lombroso-Ferrero und Victor vON BOROSINI [Übersetzung], The Results of an Official Investigation made in England by Dr. Goring to Test the Lombroso Theory, in: Journal of the American Institute of Criminal Law and Criminology 5 (2/1914), S. 207-223; EnRICO Ferri, The Present Movement in Criminal Anthropology Apropos of a Biological Investigation in the English Prisons, in: Journal of the American Institute of Criminal Law and Criminology 5 (2/1914), S. 224-227; SANTE DE SANCTIS, An Investigation of English Convicts and Criminal Anthropology, in: Journal of the American Institute of Criminal Law and Criminology 5 (2/1914), S. 228-240, S.348-363; zur Rezeption siehe auch den Bericht in The Penal Reformer 9 (1920), S. 81f.; zur Rezeption in Italien siehe RadzinOwicz und Hood, The Emergence of Penal Policy, S. $23 \mathrm{f}$.

${ }^{150}$ Lombroso-Ferrero, The Results, S. 223.

151 Ebd., S. 210.

152 Die zahlreichen Veränderungen und Zusätze (die Originalausgabe von L'uomo delinquente umfasste einen Band mit 250 Seiten, die 5. Auflage war dann dreibändig mit über 2000 Seiten) lassen sich nachlesen in: MARY GIBSON, Cesare Lombroso and Italian Criminology. 
Als 1919 eine gekürzte Neuauflage von Gorings Buch in einer populären Ausgabe erschien, fehlte darin jeglicher Hinweis auf die Anerkennung oder Kritik, die das Buch bis dahin erfahren hatte. ${ }^{153}$ Stattdessen war der Neuausgabe eine Einführung über „Charles Goring and his Contribution to Criminology“ von Karl Pearson vorangestellt worden. ${ }^{154}$ Goring war kurz zuvor, am 5. Mai 1919, an einer Lungenentzündung in Manchester gestorben. Pearson wiederholte in der Einleitung die Hoffnungen, die die Mitarbeiter des biometrischen Labors mit der Großstudie verbunden hatten: „Those who knew personally Charles Goring hoped not only that he would raise English criminology to an adequate position in continental and American estimation, but that he would ultimately succeed in moulding public and so official opinion to a sounder view of the criminal." ${ }^{155}$ Pearson pries die Studie als „epoch-making treatise on the criminal“ ${ }^{156}$ und ließ keinen Zweifel daran, dass sich die Wissenschaftlichkeit der Studie vor allem der Zusammenarbeit mit dem Labor verdankte, wo neueste Methoden und Techniken zur Anwendung gekommen seien. ${ }^{157}$

Da Pearson von der verhaltenen Rezeption der Studie wusste, konzentrierte sich seine Verteidigung ganz auf die Verteidigung der angewandten Methode. Es sei die neutrale, vorurteilsfreie und im wissenschaftlichen Sinne wahre Sprache der Mathematik, die die Ergebnisse der Studie selbst noch in einem negativen Sinne objektiv und wahr mache: „[T] he mathematical method will not create a relationship where it does not exist - as a method of appreciation, the erroneously termed ,commonsense' view, so often does. "158 Indem Pearson Gorings Ansatz verteidigte, verteidigte er seine eigene Arbeit. Doch interessanterweise verwies er nun, 1919, zur Unterstützung der These des engen Zusammenhangs zwischen erblichen mentalen Defekten und Kriminalität auch auf die Stammbaumforschung der Eugenischen Gesellschaft. Vor dem Ersten Weltkrieg hatte er sich noch sehr besorgt darüber gezeigt, dass deren Arbeit nicht mit seiner eigenen in Verbindung gebracht würde. Nun aber schien er jede Unterstützung brauchen zu können: „The accumulation of pedigrees of the mentally defective shows us beyond a doubt the heredity of mental defect, and it emphasises also the prevalence of crime in these mentally defective families. "159 Pearsons öffentlicher Hinweis

Theory and Politics, in: Becker und Wetzell (Hrsg.), Criminals and their Scientists, S. 137158. „As a comparison of the five editions of Criminal man reveals, Lombroso revised, or at least expanded, his theory in three main areas: the classification of criminals, the identity of the born criminal, and punishment.“ (Ebd., S. 142).

153 Siehe die Besprechung in The Penal Reformer 9 (1920), S. 80; die gekürzte Neuauflagevon 1919 kostete noch ein Drittel der Originalausgabe.

154 Charles Goring, The English Convict. Abridged Edition. New Issue with an Introduction by Professor Karl Pearson, London 1919.

155 Pearson, Goring, S. ix.

156 Ebd., S.ix.

157 Vgl. ebd., S. xii: „The steady collecting of data and the accumulation of measurements, followed by their analysis from the mathematical standpoint, these form the sole path to truth in criminology as in its parent science sociology."

158 Ebd., S. xiv.

159 Ebd. 
auf die Arbeit der EES lässt sich als Indiz für die relativ isolierte Position der Biometriker nach dem Ersten Weltkrieg lesen.

\section{7. „Data for speculations“: Gorings Kritiker}

Für Regierung und staatliche Verwaltungsstellen, die mit dem Rechts- und Strafsystem andere Intentionen verfolgten, war Gorings Studie eine ähnliche Herausforderung wie Lombrosos Publikation rund 30 Jahre zuvor. Zwar ließ sich der ,geborene Verbrecher ${ }^{\prime}$ ad acta legen, aber die zentrale Behauptung Gorings, eine bestimmte kriminelle Disposition sei erblich bedingt, belebten die Debatten über Determinismus und Unverantwortlichkeit von Straftätern aufs Neue. In dem der Studie vorangestellten Vorwort brachte Ruggles-Brise die Zurückhaltung und Skepsis der Prison Commission, aber auch des Innenministeriums, das sich intern seiner Meinung anschloss, ${ }^{160}$ zum Ausdruck. ${ }^{161}$ Subtil ging er zur Studie auf Distanz. Das zeigten schon die einleitenden Bemerkungen, in denen er betonte, dass die vorliegende Studie in ihrem jetzigen Ausmaß von der Prison Commission nicht intendiert worden sei, da es ursprünglich nur um die Zurückweisung oder Bestätigung bestimmter Theorien über den ,geborenen Verbrecher' gegangen sei. Dieses habe die Untersuchung geleistet, enthalte nun aber darüber hinaus „data for speculations on very difficult and contentious questions as to the relative influences of heredity, environment, \&c. "162 Angesichts der enormen Arbeitsleistung von Dr. Goring sei die Kommission aber darin übereingekommen, die Studie gemäß seiner eigenen Vorgaben erscheinen zu lassen. Allen Schlussfolgerungen indes zuzustimmen, sahen sich die Prison Commissioner ebenso außerstande wie die Methode zu kritisieren, mit deren Hilfe Goring zu seinen Ergebnissen gekommen war: „[A]ny attempt in this direction would involve an elaborate discussion of matters on which the highest scientific authorities differ." 163 Auch den Behörden war der Streit zwischen Biometrikern und Mendelianern bekannt.

Gorings zentrales Ergebnis, dass es sich beim Kriminellen in erster Linie um einen physisch und/oder mental ,defizitären` Menschen handle, nahm Ruggles-

160 Vgl. dazu Home Office Memorandum relating to the book „The English Convict“ (5 November 1913), TNA, HO 45/10563/172511; Edward Troup (Permanent Under-Secretary) und William Byrne (Board of Control) erklärten sich konform mit den Ansichten von RugglesBrise und äußerten Kritik zu einzelnen Punkten, ohne sich auf die wissenschaftlichen Debatten einzulassen, vgl. auch ForsYTHE, Penal Discipline, S. 154.

161 BEIRNE irrt mithin in der Annahme, Ruggles-Brise sei der einzige gewesen, der erkannt habe, dass The English Convict eine neue Form von ,Lombrosonismus' einführte, BEIRnE, Science, S. 213; er selbst zitiert ja sogar das Urteil H.B. Simpsons vom Home Office (ebd., S. 224), der The English Convict für „a striking example of methods borrowed from Germany where facts are lost sight of in a cloud of highly debateable figures" hielt (zit. in RADZINOWICZ und Hood, The Emergence of Penal Policy, S. 25).

162 Ruggles-Brise, Preface, S. 7, Hervorhebung S.F.; vgl. auch ders., The English Prison System, S. 198-215.

163 Ruggles-Brise, Preface, S. 7. 
Brise in seinem Vorwort das Bedrohliche, indem er für dessen Erklärung keine criminal diathesis voraussetzen zu müssen glaubte: „This general theory of defectiveness as a general attribute of criminality may be regarded [...] as confirmed by the fact that persons convicted of crime are mainly drawn from the lowest social scale; and it is plausible to infer that physical and mental inferiority is allied to a low economic scale of living. "164 Ruggles-Brise holte also den Verweis auf ungünstige Lebensbedingungen, die durchaus als Ursache für die vorhandenen physischen und geistigen Unzulänglichkeiten angesehen werden konnten, wieder in die Diskussion hinein und wehrte sich gegen Gorings Annahme, es handle sich dabei um eine konstitutionell bedingte Disposition, die mit großer Wahrscheinlichkeit erblich bedingt sei. Im ökonomischen Sinne mochte diese defectiveness, deren Existenz ja keineswegs geleugnet wurde, eine prädestinierende Funktion im Sinne einer negativen Auslese besitzen, aber sie bezeichnete keine notwendige Beziehung zu eindeutigen körperlichen Gebrechen oder Geisteskrankheit. ${ }^{165}$ In der Abwehr des Bezugs zu manifesten Krankheiten sah der Prison Commissioner jedenfalls eine faire und vernünftige Erklärung für die allgemeine Kriminalität in England. Der Grund, warum er dies wahrscheinlich tat, lag in den großen Chancen und Möglichkeiten, die der sozio-ökonomische Erklärungsansatz all jenen bot, die sich privat oder beruflich für eine Veränderung der Verhältnisse und für individualtherapeutische Betreuung engagierten. ${ }^{166}$ Hier zeigte sich nicht nur die Anerkennung für den Einsatz von Allgemeinmedizinern, Lehrern, Pädagogen, Psychologen und Sozialarbeitern, es entsprach auch dem, was zunehmend im englischen Strafsystem verfolgt werden sollte, die Individualisierung des Strafens durch Berücksichtigung des individuellen Straftäters: „Penal law, wisely and humanely administered, as in a highly civilized State, should apply its sanctions only with regard to the varying characters and capacities of those who come before the Courts." 167

Eines aber, so betonte Ruggles-Brise zugleich, dürfe weder der biologische noch der sozioökonomische Ansatz bedeuten, „[T]o call into question the whole responsibility of any person guilty of an anti-social act.“"168 Beide Ansätze waren keine Entschuldigungen für kriminelles Verhalten oder die Unmöglichkeit zu strafen. Auch Gorings allgemeine Theorie über die kriminelle Diathesis könne nicht so ausgedehnt und verstanden werden, „to affect the liability to punishment of the offender for his act. Penal law is, through its prohibition, the expression of the social standard of life in the country. Where the standard is high, there must be a residuum of individuals whose mental and physical state do not enable them to live up to this standard. "169 Alles, was in dieser Beziehung geleistet werden

\footnotetext{
164 Ebd., S. 8.

165 Ebd.

166 Vgl. dazu ebd., S. 9.

167 Ebd., S. 8.

168 Ebd., S. 9.

169 Ebd., S. 8.
} 
könne, war, auf diese konstitutionellen Defizite Rücksicht zu nehmen und durch eine geeignete Klassifizierung die Behandlung im Gefängnis entsprechend zu gestalten.

Während Ruggles-Brise und mit ihm eine ganze Reihe von Vertretern des Innenministeriums die klassischen, in Oxford ausgebildeten Regierungsbeamten verkörperten, die kein naturwissenschaftlich-mathematisches Studium absolviert hatten, meldete sich 1917 mit Sir Horatio Bryan Donkin ein praktisch ausgebildeter Arzt und Psychiater zu Wort, der auf eine fast 20jährige Tätigkeit im Umfeld der Prison Commission zurückblicken konnte. ${ }^{170}$ Als Donkin 1898 als erster Mediziner auf Empfehlung der Gladstone Kommission in die Prison Commission berufen worden war, ${ }^{171} \mathrm{kam}$ ihm im Zuge der Professionalisierung dieser Kommission unter anderem die Aufgabe zu, die wissenschaftlichen, d. h. vor allem die medizinisch-psychiatrischen Diskussionen (auch auf internationaler Ebene) zu verfolgen, die für den Komplex von Täterkonstitution und Sanktionssystem relevant sein konnten. Deshalb hatte Donkin auch Gorings Großstudie ausdrücklich befürwortet und gefördert.

Als Donkin nun als Mitglied der Medico-Psychological Society seine erste Kritik an Gorings Studie im Journal of Mental Science veröffentlichte, ${ }^{172}$ war er bereits aus dem aktiven Dienst ausgeschieden, arbeitete aber immer noch ehrenamtlich als Mitglied des lokalen Beratungskomitees, das für die Auswahl von verurteilten Gewohnheitsverbrechern zuständig war, die in das Reformgefängnis Camp Hill auf der Isle of Wight überstellt werden sollten. ${ }^{173}$ In dieser Funktion hatte Donkin bereits Hunderte von Eignungsgesprächen mit Rückfalltätern durchgeführt. Begeistert von der Idee, die Camp Hill in seinen Augen verkörperte, setzte Donkins Kritik gezielt an denjenigen Ergebnissen von Gorings Studie an, die solche Reformmodelle in Frage stellten. Dabei konzentrierte er sich zunächst auf eine ,neutrale' Methodenkritik.

Donkin bezweifelte nicht die Tatsache, dass es bei allen menschlichen Handlungen eine anlagebedingte Abhängigkeit gab, ${ }^{174}$ aber Gorings Behauptung, dass das menschliche Wesen, kriminell oder nicht-kriminell, vor allem und nahezu ausschließlich ein Geschöpf dieser „inborn capacities“175 sei, hielt er für falsch und überdies für anmaßend, da man diesen Beweis mit der biometrisch-statistischen Methode überhaupt nicht antreten könne. Es sei unmöglich, mit Präzision den proportionalen Anteil des Einflusses von Anlage und Umwelt in der Entwick-

170 Vgl. BRYAN DonkIn, The Factors of Criminal Actions, in: The Journal of Mental Science 65 (1919), S. 87-96, hier S.96 zu seiner langjährigen Tätigkeit und den Hunderten von Interviews, die er mit Strafgefangenen geführt hat.

171 Siehe dazu Forsythe, Penal Discipline, S. 153.

172 Byran Donkin, Notes on Mental Defect in Criminals, in: The Journal of Mental Science 63 (1917), S. 16-35; zu seiner Mitgliedschaft in der Medico-Psychological Association siehe THE HOWARD JOURNAL 1 (3/1924), S. 105.

173 Dem Camp Hill Advisory Committee gehörten sechs Mitglieder an, siehe THE HowARD Journal 1 (1/1921), S. 20; siehe auch Forsysthe, Penal Discipline, S. 154.

174 Donkin, Notes on Mental Defect, S. 31.

175 Ebd. 
lung des Kriminellen zu bestimmen. ${ }^{176}$ Generell schien es Donkin fraglich, ob sich durch die Auswertung von Massendaten und die daraus abgeleiteten Verallgemeinerungen überhaupt relevante Empfehlungen für die praktische Behandlung von Straftätern gewinnen ließen, so groß seien die Unterschiede der beobachtbaren Charaktere von beiden, Kriminellen und Nicht-Kriminellen. ${ }^{177}$

Gerade in Bezug auf die Feststellung geistiger Defekte bezweifelte Donkin die Vorteile, die die biostatistische Statistik gegenüber der herkömmlichen Differentialdiagnostik haben sollte. Um sie bei kranken Straftätern festzustellen, bedürfe es keiner komplizierten mathematischen Methoden, sie ergebe sich schon aus der klinischen Beobachtung. Die mindere Intelligenz, die Goring als eine Bezugsgröße in seinen Untersuchungen eingesetzt habe, sei nicht aus den statistischen Analysen selbst hervorgegangen, sondern basiere auf der zuvor vom Gefängnisarzt vorgenommenen Feststellung, d.h. mindere Intelligenz oder mentale Defekte als Variablen gingen allen Bezugssetzungen voraus. Auch neue Erkenntnisse über die zerebralen Abläufe und Prozesse würden durch sie nicht gewonnen. ${ }^{178}$ Nach Donkins Auffassung bot also die biostatistische Methode keine Alternative zur klinischen Beobachtung. Auch ließ sich ihr keine klare Handlungsanweisung im Umgang mit kranken Straftätern entnehmen. ${ }^{179}$

Der ehemalige Prison Commissioner präferierte demgegenüber ein dynamisches Modell, das dem Einfluss von Umwelt und Anlage paritätisch Rechnung trug, indem es bei der Genese von Kriminalität von einer permanenten Interaktion beider Faktoren ausging. Wie Goring verneinte Donkin einen prinzipiellen Unterschied zwischen kriminellen und nicht-kriminellen Menschen. Allein der Erwerb sozialer Kompetenz, das geglückte bzw. verfehle Einüben in ein von Normen bestimmtes gesellschaftliches Dasein war nach seiner Auffassung sozial vermittelt und nicht biologisch bestimmt: „The study of criminals has, indeed, long convinced me that all men are potential lawbreakers, and that without the traditional (not biological) heritage or moral or social experience, human society would be dissolved. "180 Auch Donkin entpuppte sich also als ein Fürsprecher der bemerkenswerten Erziehbarkeit und Lernfähigkeit des Menschen. ${ }^{181}$ Seiner Überzeugung zufolge gingen konkrete menschliche Eigenschaften sowohl auf die angeborene Fähigkeit zurück, sie überhaupt entwickeln zu können, als auch auf das

176 Siehe ebd., S. $31 \mathrm{f}$. „The totality of the complex environment which moulds the characters of men - ,physical', , mental', , moral', or ,intellectual ${ }^{\star}$ - and either encourages or stunts the development of their natural or inborn capacities, cannot be analysed or reduced to such items as can be established or eliminated or reasonably dealt with by statistical handling. It is not possible to ,disentangle the various factors that contribute to the production of a criminal." (S. 32); „This, as well as his account of the items or ingredients which constitute his conception of the ,criminal diathesis', tend to illustrate the unfitness of applying solely biometrical methods to all branches of biological research." (ebd., S. 27).

177 Donkin, Factors of Criminal Actions (1919), S. 96.

178 BRYAn Donkin, Occasional Notes on the Mental Deficiency Act, in: The Journal of Mental Science 62 (1916), S. $475 \mathrm{f}$.

179 Siehe DonkIN, Notes on Mental Defect, S. 23.

180 Ebd., Hervorhebung im Original.

181 Ebd., S. 25. 
Vorhandensein externer Einflüsse, die für ihre Entwicklung geeignet und günstig waren. Viele der inborn capacities blieben un- oder unterentwickelt, da es an geeigneter externer Stimulation fehlte. ${ }^{182}$ Umgekehrt gab aber Donkin durchaus zu, dass externe Stimuli wenig bewirken konnten, wenn entsprechende angeborene Fähigkeiten fehlten. ${ }^{183}$ Dennoch - den Möglichkeiten von Erziehung bzw. Erziehbarkeit hätte Goring zu wenig Aufmerksamkeit geschenkt, und seine Schlussfolgerung, auf die Reformierbarkeit der Verbrechers könne aufgrund seiner angeborenen minderen Intelligenz getrost verzichtet werden, sei falsch. ${ }^{184}$ Donkin wollte hingegen weder aus verminderter Intelligenz die Unmöglichkeit einer Reformierung von Straftätern ableiten noch einer Unverantwortlichkeit des Straftäters das Wort reden. ${ }^{185}$ Mochte die Mehrheit der Straftäter tatsächlich eine geringere Intelligenz aufweisen als die Vergleichsgruppe der gesetzestreuen Bürger, sie als praktisch unverantwortlich zu betrachten oder gar zu behandeln ergab sich für Donkin daraus nicht. ${ }^{186}$

Wie Ruggles-Brise verkörperte Donkin in dieser Frage die typische Haltung des civil service, der an der Vorstellung der Verantwortlichkeit als einer für das soziale Zusammenleben unverzichtbaren regulativen Idee festhielt. Sicher gab es unverantwortliche Geisteskranke aber Menschen mit bloß verminderter Intelligenz durften nicht mit ihnen auf eine Stufe gestellt werde. ${ }^{187}$ Selbst wenn sich nicht aufschlüsseln ließ, unter welchen Voraussetzungen und Einflüssen Menschen Handlungen vollzogen, und selbst wenn man von einer Abhängigkeit von biologischen Funktionen ausgehen musste, so galt es dennoch die Idee einer Handlung aus freiem Willen notwendigerweise aufrecht zu erhalten. Jedes um Identität bemühte Individuum müsse sich, so Donkin, als ein dazu fähiges Wesen selbst so wahrnehmen und werde von anderen auch so wahrgenommen:

In practical life men assume a general ability to choose their lines of action; and also the reality of themselves and other men, and of the external world at large; and most people when they think about causation regard it as meaning something more than a simple sequence of sense impressions. They still act on these assumptions or beliefs as if they were true. ${ }^{188}$

Den experimentellen Nachweis eines freien Willens hielt Donkin weder für möglich noch für notwendig. Politisch notwendig erschien es ihm allerdings, diese Annahme konsequent aufrecht zu erhalten.

182 Übernimmt hier die Ausführungen von Archdall Reid, siehe DonkIN, Notes on Mental Defect, S. 25.

183 Ebd, S. 26.

184 Ebd., S. 32.

185 Goring wendete ein, dass Voraussage nicht Vorherbestimmung sei, vgl. GoRING, Etiology of Crime, S. $132 \mathrm{f}$.

186 DonkIn, Notes on Mental Defect, S. 33.

187 „Even if the view that no ill-doer or antisocial member of a community can help ill-doing - a view which entails [...] the inference that well-doing is similarly conditional - should be held by some in moments of bemused study, human social existence will still proceed on the assumption of the old notion of responsibility." DonKIn, Notes on Mental Defect, S.21.

188 Ebd. 


\subsection{Die Prison Commission und die Sterilisation von Straftätern}

Nur selten werden wissenschaftliche Debatten über die Beschaffenheit des Menschen rein wissenschaftlich geführt. Oft verbergen sich dahinter politische Auseinandersetzungen. Auch Donkin beschränkte sich in seiner Kritik an Gorings Studie nicht auf eine wissenschaftliche Methodendiskussion, sondern entpuppte sich als zeitgenössischer Kritiker eines wachsenden Deutungsanspruchs von Wissenschaftlern, den er politisch für hochgradig bedenklich hielt. Verwundert zeigte er sich 1917 darüber, wie viele Gruppen sich inzwischen mit Fragen von Kriminalität und Täterkonstitution beschäftigten und sich dabei vorzugsweise auf „scientific authorities“ beriefen. Besonders ärgerte ihn dabei die Führungsrolle, die Karl Pearson und sein biometrisches Labor dabei beanspruchten: „It must not be forgotten that many writers on crime make definite claims that their special teaching is ,scientific', and that some deny that any method of inquiry other than their own is scientific at all." 189 Das Einsickern wissenschaftlicher Deutungen in politische Entscheidungsprozesse war nach Ansicht des Prison Commissioner mit großen Gefahren verbunden, da durch Unsicherheit oder Unwissenheit auf bestimmten Gebieten sozialpolitisch engagierte Laien und Politiker nur allzu gerne auf die Expertise wissenschaftlicher Autoritäten zurückgriffen. Umgekehrt konnte derjenige, der dabei als wissenschaftliche Kapazität auftrat, beachtlichen Einfluss ausüben „on serious inquirers, social workers, and legislators, who make no pretence to first-hand study of the subject, but are naturally eager, especially when a measure of legislation is in the air, to find some expert authority on which they may found their opinions and actions." 190

Die Trennung von Wissenschaft und Politik als zwei voneinander unabhängige und autonome Bereiche erschien Donkin notwendig, aber auch stets gefährdet, denn er hatte den Eindruck, dass die Instrumentalisierung wissenschaftlichen Wissens für politische Zwecke auch von bestimmten Wissenschaftlern gerne in Kauf genommen wurde. Karl Pearsons diesbezügliche Werbung in eigener Sache war niemandem entgangen. ${ }^{191}$ Auch der Mendelianer William Bateson hatte auf die Auswirkungen und Konsequenzen hingewiesen, die sich aus dem Einfluss neuer wissenschaftlicher Erkenntnisse auf das Rechtssystem eines Staates ergeben konnten: „Genetic knowledge must certainly lead to new conceptions of justice, and it is by no means impossible that in the light of such knowledge public opinion will welcome measures likely to do more for the extinction of the criminal and degenerate than has been accomplished by the ages of penal enactment. "192 Donkin führte diese Verlautbarung als Beispiel für eine in ihrer Logik bestechen-

189 Beide Zitate: ebd., S. 19.

190 Ebd., S. 19.

191 Siehe z. B. Pearsons programmatische Schrift, ders., National Life from the Standpoint of Science, London 1900.

192 William Bateson, zit. in DonkIN, Notes on Mental Defect, S. 20. 
de Aussage an, die ihre Wirkung auf eine unkritische Öffentlichkeit nicht verfehlen würde, da ihr eine alltagstaugliche Plausibilität nicht abzusprechen sei. ${ }^{193}$ Für ihn lag die Gefahr genau in diesem Übergang wissenschaftlicher Aussagen, populär verkürzt und aus ihrem komplexen Herstellungskontext herausgenommen, in einen unreflektierten und mit Vorurteilen belasteten öffentlichen Diskurs.

Obgleich niemand zu diesem Zeitpunkt in der Lage war, komplexe Vererbungsmechanismen adäquat erklären oder auch nur beschreiben zu können, lieferten Begriffe wie „inherited criminality“ ausreichende Erklärungen für diejenigen, „who are content to substitute undefined words for definite things“. 194 Wohin das führen konnte, demonstrierte Donkin am Beispiel der 1907 verabschiedeten Sterilisationsgesetze des amerikanischen Bundesstaates Indiana, die die Fortpflanzung von „confirmed criminals, imbeciles, idiots, and rapists“ untersagten. ${ }^{195}$ Der Entwurf des Gesetzes war zunächst an das Committee of State Medicine, Health, and Vital Statistics gegangen und dann an das Committee of Benevolent and Scientific Institutions weitergereicht worden. ${ }^{196}$ Das endgültige Gesetz legitimierte schließlich Sterilisation auch ohne Zustimmung der Betroffenen aufgrund eines einzigen, einführenden Satzes. Dieser Satz erklärte die nie nachgewiesene und hoch umstrittene Behauptung, Kriminalität sei erblich bedingt, zur unumstößlichen Tatsache: „Whereas, Heredity plays a most important part in the transmission of crime, idiocy and imbecility“. 197 Mit Hilfe dieses Satzes, der nach Donkins Einschätzung auf „crude, ill-worded, and ill-considered statements“198 basierte und aus Meinungen Fakten werden ließ, wurden nun drastische Maßnahmen gegen Bürger legitimiert. Den Kritikern des sozialpolitischen Programms der Eugenischen Gesellschaft ähnlich kritisierte Donkin hier die Verabschiedung eines Gesetzes, dessen wissenschaftliche Begründung mehr als angezweifelt werden musste. ${ }^{199}$ Zusammen mit anderen Prison Commissioners ging er in den Zwischenkriegsjahren auf offenen Konfrontationskurs zu den eugenischen Populisten im

193 Ebd., S. 20.

194 Beide Zitate: ebd.

195 Zwischen 1907 und 1917 erließen 11 weitere amerikanische Staaten Sterilisationsgesetze; bis Mitte der 1920er Jahre waren über 3000 Gewohnheitsverbrecher sterilisiert worden, siehe DAVIE, Tracing the Criminal, S.253, ebd. S. 266 (weitere Literatur); KeLVES, In the Name of Eugenics, S.93, S.218; Nicole HaHn Rafter, Creating Born Criminals, Urbana/Ill. 1997, Kap.7-8; dies., Criminal Anthropology in the United States, in: Becker und Wetzell (Hrsg.), Criminals and their Scientists, S. 159-181.

196 Zeitgenossen konnten Angaben zu Sterilizationen nachlesen bei R.A. GibBOns, The Treatment of the Congenitally Unfit and of Convicts by Sterilization, in: Eugenics Review 18 (1926), S. 100-109; Harry H. LAUGHLIN [Superindentent des amerikanischen Eugenics Record Office], Eugenical Sterilization in the United States, Chicago 1922; vgl. Forsythe, Penal Discipline, S. 158; GILlHam, Francis Galton, S. 353.

197 Siehe das Gesetz unter https://idea.iupui.edu/dspace/bitstream/1805/1053/2/1907\%20 General\%20Acts-\%20fast\%20download_A1b.pdf, Kap. 215, S. 377f. (15.09. 2012).

198 Donkin, Notes on Mental Defect, S. 20.

199 Scharfe Kritik am Sterilisationsgesetz von Indiana übte auch die British Medical Association, die der Ansicht war, „it would lower those who practised it to the level of the hangman“, Kommentar auf S. 1, The British Medical Journal 2 (1913), S. 508f., hier S. 509; siehe auch Radzinowicz und Hood, The Emergence of Penal Policy, S. 324. 
eigenen Land. ${ }^{200}$ In den frühen 1920er Jahren lieferte er sich einen öffentlichen Schlagabtausch mit dem angesehenen Psychiater und Eugeniker Alfred Tredgold über die Sterilisation von Sexualverbrechern und sprach sich vehement dagegen aus. ${ }^{201}$

Protest kam auch von Mitarbeitern staatlicher Psychiatrien. John Baker, der Superintendent der Psychatrieanstalt für Straftäter in Broadmoor erinnerte in einem Brief an das Home Office daran, welche Katastrophe bei geistig kranken Patienten Sterilisationsmaßnahmen auslösen könnten. Sie würden die schlimmsten obsessiven Phantasien der Patienten Wirklichkeit werden lassen, „that doctors were actually mutilating patients [...] these ideas would assume a concrete form and would be fraught with very serious consequences indeed."202 Auch der 1929 neu berufene Medical Prison Commissioner William Norwood East schrieb im März 1933 ein langes Memorandum an das Departmental Committee on Sterilisation, ${ }^{203}$ das sich unter dem Vorsitz von Alfred Tredgold mit Fragen der freiwilligen Sterilisation von geistig kranken und zurückgebliebenen Personen beschäftigte, in dem er erklärte:

200 Vgl. Forsythe, Penal Discipline, S. 157; auch ein privater Brief Donkins an Ruggles-Brise verrät die Einstellung der Prison Commission zur Frage von Anlage und Umwelt. Donkin beschreibt Ruggles-Brise in diesem Brief den Inhalt eines geplanten Vortrags: „The chief burden of my song is the importance of mental acquirements (which have to be taught) to human progress and achievement, or, in other words, the great part played in the mental development of everyone by the agency of traditional heritage, as distinct from natural inheritance or ,heredity'. And I have always remembered a condensed expression you used once, when I was talking to you about these matters in your room several years ago (when you were laid up with your wounded leg), viz. - that the power of recording experience seemed to you to be the most important, differentia' between man and all other creatures. It was this remark that seemed to me on long subsequent reflection [...] to sum up most precisely the position of those who, like myself, oppose the doctrine of the omnipotence of natural heredity in the development of all the specific qualities and abilities of individuals;" Bryan Donkin an Evelyn Ruggles-Brise, 23. Juli 1910, abgedruckt in: SHane, Sir Evelyn Ruggles-Brise, S. $151 \mathrm{f}$.

201 Vgl. Bryan Donkin, The Times, 19. Dezember 1923, S. 11, Sp. e; Bryan Donkin, The Times, 26. Juni 1924, S.12, Sp. c-d; Bryan Donkin an das Home Office, 20. Juli 1910, TNA, HO 144/1088-194663/4; Forsythe, Penal Discipline, S. 158; zu Alfred Tredgold siehe HearnshaW, Short History of British Psychiatry, S. 154.

202 John Baker an das Home Office, 7. Januar 1911, TNA, HO 144/1088-194663/4 (Expert Opinion on Sterilization); vgl. ForsYTHE, Penal Discpline, S. 158.

${ }^{203}$ Das aus Mitgliedern des Board of Control zusammengesetzte Brock Committee knüpfte an die Empfehlungen des Wood Committee [1924 aus Mitgliedern des Board of Education und des Board of Control zusammengesetzt, Bericht 1929] an und beriet die Frage der freiwilligen Sterilization von mental defectives; das Komitee sprach sich für die freiwillige Sterilisation aus, aber nur unter strenger juristischer Kontrolle. Vgl. Board of Control, Report of the Departmental Committee on Sterilisation [The Brock Committee], Parliamentary Papers 1934, Cd. 4485; „But while they concluded“, so kommentiert Nikolas Rose die Ergebnisse des Kommitees, „with what was perhaps the last official plea for a eugenic strategy, their recommendations were never turned into legislation, and their plea already sounded outmoded." Rose, Psychological Complex, S. 143; die wachsende Betonung von sozialen und Umweltfaktoren, die eher nach einer sozial-psychologischen Behandlung verlangten (vgl. Kap.6), ließ die Forderung nach Sterilisation verblassen. 
It is inconceivable that this country will submit to the eugenic sterilization of its criminals unless substantial reasons are produced in support of the practice. So far these are lacking [...] eugenic sterilization as a means of combating delinquency appears previous, unwarranted and possibly harmful to the race. As a punitive measure it is outrageous. As a therapeutic measure it is otiose, may incite to sexual crime and lead to a false sense of security in the public mind. ${ }^{204}$

Mit Bryan Donkin und seinen kritischen Einwänden gegen die Ergebnisse von Gorings Studie und mit William Norwood East, seinem Nachfolger, blieb die Prison Commission eine Institution, die sich konsequent eugenischen Forderungen in Bezug auf die Sterilisation von Straftätern widersetzte, ganz gleich, welche populären öffentlichen Wellen diese Diskurse schlugen und welche wissenschaftlichen Autoritäten sich dafür aussprachen. ${ }^{205}$ Unterstützt wurde sie darin auch von der einflussreichen British Medical Association und besonders von Donkins Kollege, Charles Mercier, dem Präsidenten der Psychologischen Sektion dieser Vereinigung. Es war jener Charles Mercier, der schon 1904 Galtons Vortrag scharf kritisiert und es in den folgenden Jahren nicht versäumt hatte, immer wieder zu dieser Frage Stellung zu nehmen. ${ }^{206}$

1935, zwei Jahre nach dem East-Memorandum, verdeutlichten die Verhandlungen des 11. Internationalen Gefängniskongresses, der diesmal in Berlin stattfand, wie weit die Kriminalitäts- und Strafkonzepte der Prison Commissioner von den Auffassungen ihrer deutschen Kollegen aus dem Bereich der Rechtsprechung und des Strafvollzugs entfernt waren. ${ }^{207}$ Wie ihr Vorgänger Evelyn Ruggles-Brise interessierten sich auch Alexander Paterson und Harold Scott, der Vorsitzende der Prison Commission von 1932-1938, für die kriminalpolitischen Entwicklungen und Modelle des Auslands. Paterson hatte zu diesem Zweck bereits in den späten 1920ern Jahren Gefängnisse in Asien und Amerika besucht, Scott war 1934 nach Deutschland gereist, um einige ,Modell-Gefängnisse` aufzusuchen. Mit dem Gefühl von Depression habe er einige von ihnen wieder verlassen, schrieb er später in seinem offiziellen, 1936 publizierten Bericht. Unter den Inhaftierten habe völlige Resignation geherrscht, und eine überstrenge und harsche Gefängnisaufsicht habe jederzeit unmissverständlich für Ruhe und Ordnung gesorgt. ${ }^{208}$ Was Scott besonders irritierte, war das offensichtliche Bestreben der deutschen Gefängnisverwaltung, jeden Selbstrespekt des Inhaftierten zu zerstören. Man habe ihm mitgeteilt, der Wille des Inhaftierten müsse gebrochen werden, um in ihm eine neue Haltung gegenüber der Volksgemeinschaft zu erzielen: „he who will not hear must

204 William Norwood East, Sterilization Committee 1932-1933, Memorandum submitted to the Departmental Committee on Sterilization, 27 March 1933, TNA, PCOM 9/123.

205 Siehe dazu die Akten des Innenministeriums zu Sterilisation und Mental Deficiency, 19111934, TNA, HO 144/19778-197900/30/69/72/77.

206 Siehe z. B. Charles Mercier, The Lancet (9.August 1913), S. 400; auch Forsythe, Penal Discipline, S. 155 und S. 158.

207 Siehe zum Folgenden besonders William J. ForsYThe, National Socialists and the English Prison Commission: The Berlin Penitentiary Congress of 1935, in: International Journal of the Sociology of Law 17 (1989), S. 131-146; Forsythe, Penal Discipline, S. 233-235; FreITAG, Reichweite und Grenzen einer Internationalisierung, S. $163 \mathrm{f}$.

208 Harold Scott, German Prisons in 1934, Maidstone (H.M. Prison) 1936, S. 85. 
feel [...] he who sets himself against the law must be shown clearly by his sentence and the mode of its infliction that the community stands above the individual." 209 Scott erwähnte in seinem Bericht auch die wachsende Neigung der deutschen Rechtsprechung, mit Hilfe biologistischer Theorien über die Weitergabe geistiger und körperlicher Defizite eugenische Maßnahmen zu rechtfertigen. Sterilisation, so kommentierte er, werde bei Alkoholikern und Geisteskranken vorgenommen, Homosexuelle und sexuelle Straftätern würden zur Strafe und Prävention kastriert. ${ }^{210}$

\section{Der Internationale Gefängniskongress in Berlin (1935)}

Bereits 1930 war auf dem Prager Kongress Berlin als nächster Tagungsort festgelegt worden. Doch nach Hitlers Machtergreifung 1933 wuchs in Großbritannien die Besorgnis über eine britische Teilnahme am 11. Kongress in der deutschen Reichshauptstadt. Bischöfe der Church of England und jüdische Mitbürger rieten von einer Teilnahme ab. ${ }^{211}$ Als Denis Pritt, der Vorsitzende der Howard League for Penal Reform, mit einem Einreiseverbot nach Deutschland belegt wurde, weil er es öffentlich gewagt hatte, die nationalsozialistische Version der Vorgänge des Reichstagsbrandes zu bezweifeln und ihre juristische Behandlung zu kritisieren, entschieden die Mitglieder der Howard League geschlossen dem Kongress fern zu bleiben. ${ }^{212}$ Anfang 1935 hatte das Reichsjustizministerium Alexander Paterson offiziell davon in Kenntnis gesetzt, dass die nationalsozialistische Regierung Pritt als Landesfeind betrachte. Paterson wiederum wollte durch diesen Vorfall die Harmonie des Kongresses nicht gefährdet sehen. ${ }^{213}$ Doch im Gegensatz zum Prager Kongress, zu dem neben den offiziellen Mitgliedern der Prison Commision über 100 britische Sozialarbeiter, Philanthropen, magistrates, Gefängnisangestellte und

209 Ebd., S. 25.

210 Vgl. ebd., S. 93; zum Strafvollzug im NS-Staat siehe NiKOLAUS WACHSMANN, Gefangen unter Hitler. Justizterror und Strafvollzug im NS-Staat, München 2004.

211 So hatte 1934 bereits der Erzbischof von Canterbury beim Innenminister Sir John Gilmour über die Behandlung von Juden in Deutschland protestiert, aber das Home Office glaubte durch eine offizielle Beschwerde nur das Risiko zu erhöhen, dass die deutschen (sic) Teilnehmer dem Kongress fernbleiben würden.

212 Siehe dazu die Erklärung in The Howard Journal 4 (2/1935), S. 132: „The Howard League abstained from participation in the Berlin Congress of the International Penal and Penitentiary Commission because it had good reason to believe that the Congress would lack that freedom in the choice of delegates, freedom of speech and freedom in reporting without which an international gathering is doomed to futility. We refrain from comment on the proceedings of the Congress, save to quote the Times leader which, after the close of the meeting, said ,The International Penal Congress [...] was mainly a saddening and unprofitable business."

213 Forsythe, National Socialists and the English Prison Commission, S. 137; er bezieht sich hier auf die Unterlagen der Prison Commission TNA, PCOM 9/195 und 196 (International Penitentiary Congress Berlin 1934-1936) und die Unterlagen des Home Office, TNA, HO 45/20458-553922 (International Penitentiary Congresses 1930-1935). 
Mitglieder von Reformgesellschaften angereist waren, ${ }^{214}$ wurde 1935 die kleine offizielle britische Delegation - bestehend aus Alexander Paterson, Lord Polwarth, dem Vorsitzenden der Schottischen Prison Commission, ${ }^{215}$ und dem Arzt A.H. Norris von der Children's Branch des Innenministeriums ${ }^{216}$ - nur von 20 inoffiziellen Teilnehmern begleitet, darunter der mit sehr guten Deutschkenntnissen ausgestattete sozialistische Anwalt Geoffrey Bing, der später in einem Artikel für das Howard Journal über das skurrile Schauspiel berichtete. ${ }^{217}$ Wie sehr sich in Deutschland inzwischen auch die Lage für die liberalen Reformkreise vor allem unter den Juristen verschlechtert hatte, demonstrierte die Zusammensetzung der deutschen Delegation. Sie bestand aus 443 Teilnehmern, von denen allerdings nur 19 auch am Kongress in Prag teilgenommen hatten. „Those who desired to renew old friendships“, kommentierte Bing, „could find little consolation in the fact that the places of their [...] lost friends were filled by four hundred and twenty-four new German delegates without Congress experience." 218 Als jedoch diese aufgeblähte deutsche Delegation das Bestreben zeigte, die Abstimmungsregeln des Kongresses dahin gehend zu ändern, dass einzeln nach Delegierten und nicht nach Nationen abgestimmt werden sollte, scheiterte dieser Versuch am britischen, belgischen und norwegischen Protest. ${ }^{219}$ Sie hätte ein klares Übergewicht der deutschen Stimme garantiert.

Die Nationalsozialisten nutzten den Kongress geschickt zur eigenen Propaganda. Den Auftakt bildete die Rede von Reichsjustizminister Dr. Franz Gürtner, der über „The Idea of Justice in German Penal Reform“ sprach. ${ }^{220}$ Er erinnerte an das

214 Eine instruktive und zugleich unterhaltsame Beschreibung des Prager Kongresses von Arthur Robert Lee Gardner, The Tenth International Penal and Penitentiary Congress at Prague in 1930, findet sich in: The Howard Journal 3 (2/1931), S. 83-85: „An expedition by special train to Pilsen afforded the members of the Congress an opportunity to inspect the prison in that town and likewise the famous brewery - the day was indeed divided almost equally between cells and cellars" (S. 85).

215 Walter George Hepburne-Scott, 9th Lord Polwarth (1864-1944) war von 1909-1929 Vorsitzender der Schottischen Prison Commission, siehe Forsythe, Penal Discipline, S. 233.

216 Bevor Norris 1917 in die Children's Branch des Home Office berufen wurde, hatte er als Medical Inspector gearbeitet, siehe JOHN ClARKE, Managing the Delinquent: the Children's Branch of the Home Office, 1913-30, in: Mary Langan und Bill Schwarz (Hrsg.), Crises in the British State, 1880-1930, London 1985, S.240-255, hier S.245; ausführlicher zu Norris vgl. auch Kap. 6.4. dieser Arbeit.

217 Siehe Geoffrey H.C. Bing, The International Penal and Penitentiary Congress, Berlin, 1935, in: The Howard Journal 4 (2/1935), S. 195-198; obwohl Paterson versucht hatte, auch Mitglieder der Association of Prison Visitors, der Church of England Temperance Society und der National Association of Probation Officers zur Mitfahrt zu bewegen, war die Reaktion äußerst verhalten, siehe ForSYTHE, National Socialists, S. $137 \mathrm{f}$.

218 BING, International Congress, S. 198.

219 Siehe Forsythe, National Socialists, S. 140.

220 Diese Reden wurden in Deutsch gehalten, hier zit. nach dem Bericht von BING, International Congress, S. 195; zumindest in den einzelnen Sektionen (Administration, Legislation, Prevention) war es Usus, englische oder französische Übersetzungen zur Verfügung zu stellen, allerdings scheint sich der Berliner Kongress durch eine diesbezüglich sehr schlechte Organisation ausgezeichnet zu haben: „In the Legislation Sektion, at any rate, the English translation of the proceedings, on the rare occcasions when it was provided, was incomprehensible.“ (ebd. S. 198). 
gesunde Volksempfinden, das alle Gerichte in ihrer Urteilsfindung leiten werde: "As the leadership in Germany is constantly endeavouring to be the incorporated expression of the people's will, the judge finds both in the Fuhrer's will and also in the national consciousness, bearings from which he can obtain the guiding line for his decisions. “221 Roland Freisler, der spätere Präsident des Volksgerichtshofes, sprach in einer ausladenden Rede über „The Change in the Political Outlook in Germany and its Influence on the Progress of the Criminal Law, Penal Procedure and the Execution of Sentences“.222 Er hob den großen nationalen Reinigungsprozess hervor, der nun durch die Rechtsprechung und den Strafvollzug einsetze. ${ }^{223}$ Die Verletzung, Kränkung und der empfundene Ekel des Volkes gegenüber dem Täter müsse diesem durch die härteste Gefängnisdisziplin zu Bewusstsein gebracht werden, bevor er die Möglichkeit erhalten könne, dem Volk gegenüber Abbitte zu leisten. ${ }^{224}$ Der Engländer Bing zeigte sich besonders über Freislers Versuche beeindruckt, „to justify vindictive punishments on mystical grounds“.225 Hans Frank, Leiter des Reichsrechtsamts der NSDAP, nutzte die Abendveranstaltung in der Akademie für Deutsches Recht nicht nur, um allgemein über den Schutz von Volk und Rasse vor Kriminellen, die als bösartige Krankheit die nationale Volksgesundheit bedrohten, zu sprechen, sondern zugleich zur gemeinsamen Front gegen die politischen Kriminellen in Russland aufzurufen. Am nächsten Morgen sprach schließlich Joseph Goebbels über Innenansichten Deutschlands und die konstruktive Arbeit des nationalsozialistischen Staates, ein Thema, wie Bing befand, das für sich genommen interessant sein mochte, aber in keiner Weise etwas mit dem Kongress zu tun hatte: „Indeed, none of the set speeches had any relation to the matters on the agenda. They all of them consisted of defence and explanation of National Socialist policy. "226 Allein, die deutsche Presse und selbst juristische Fachblätter wie die Deutsche Justiz berichteten fast ausschließlich über die Reden des nationalsozialistischen Führungskaders.

Das hatte auch damit zu tun, dass sich Vorträge wie die von Alexander Paterson, der darauf beharrte, dass der Zweck von Gefängnisstrafen ein erzieherischer und reformerischer sein müsse, so deutlich von der offiziellen deutschen Rhetorik absetzten. ${ }^{27}$ Auch das in der Präventions-Sektion verlesene Papier von William Norwood East, das seine Einwände gegen die Sterilisation von Strafgefangenen wiederholte, weil sie wissenschaftlich nicht zu rechtfertigen und völlig inakzeptabel sei, verpuffte in einer seltsam unwirklich anmutenden Atmosphäre, wie Bing schrieb, in der von der Mehrheit der Teilnehmer alle Reformbemühungen von

221 Gürtner zit. nach der wörtlichen Wiedergabe in BiNG, International Congress, S. 195f.; zu Gürtner und seiner Beteiligung am Urteil zum Reichstagsbrand (Todesstrafe gegen den Kommunisten Marinus van der Lubbe als Maßnahme im Kampf gegen das ,internationale Terroristentum") siehe WACHSMANN, Gefangen unter Hitler, S. 60-65.

222 Siehe BING, International Congress, S. 196.

223 Siehe die Zusammenfassung bei Forsythe, National Socialists, S. 138-140.

224 Siehe ebd., S. 140.

225 Bing, International Congress, S. 196.

226 Ebd.

227 The Times, 24.August 1935, S. 9, Sp. c. 
Straftätern ohnehin prinzipiell in Frage gestellt wurde. ${ }^{228}$ Ihnen allen klang die Erklärung Franks im Ohr: „The Nazi Jurist is a fanatical exponent of the principle of reprisal and of intimidation" 229 Durch das Übergewicht der deutschen Delegation entstand auch der Eindruck, der Kongress stimme mit großer Mehrheit für die Sterilisation von Straftäter, was nicht der Fall war: „It appeared“, so schilderte Bing den Eindruck, " that the German view on sterilisation was carried by an overwhelming majority. Actually those few hands which were raised against it in the Plenary Assembly represented the opinion of at least half the civilised world. “230 Hinzu kamen Sprachverwirrungen, die auszuräumen offensichtlich nicht das Bestreben der Veranstalter war: „A certain chaos and confusion marked all the deliberations of the Congress. To the writer's [Bing's, S.F.] certain knowledge, one official American delegate who had a particular interest in the subject voted for the sterilisation resolution under the impression that he was voting against it. When the result was announced he still failed to discover his error and left the hall with the impression that the anti-sterilisation party had won by a large majority. “231 Dass der Kongress am 24.August 1935 schließlich in einer, wie die Times schrieb, „atmosphere of confusion and haste which characterised it from the beginning“, zu Ende ging, führte die Zeitung auf „the unduly large proportion of time taken up by the voluntary lectures of German government spokesmen in defence of National Socialist ideas" 232 zurück.

Während Paterson im Anschluss an den Kongress die von ihm erwarteten diplomatischen Höflichkeiten austauschte und den Organisatoren des Kongresses versicherte, dass „the friendship of Germany and England has been strengthened by our time with you in Berlin", 233 zeugen die von ihm und Polwarth dem Home Office intern gegenüber gemachten Bemerkungen von einer ganz andern Einschätzung: Kein deutscher Delegierter habe es gewagt, gegen die nationalsozialistische Doktrin aufzubegehren, und so sei der ganze Kongress zu einer einzigen Propagandaveranstaltung der Nationalsozialisten verkommen. ${ }^{234}$ Als einen „congress in chains" 235 schilderte auch Geoffrey Bing die Berliner Verhandlungen bei einem Treffen der Howard League im November 1935: „[I]t is useless to attempt to fight the worst evils of the Nazi regime by the methods of negotiation and

228 Dr. William Norwood East on Sterilization, TNA, PCOM 9/196-32 (International Penitentiary Congress Berlin 1934-1936), kein Datum, bezieht sich auf das „Memorandum submitted to the Departmental Committee on Sterilization by William Norwood East", 27 March 1933, TNA, PCOM 9/123; siehe auch ForsYTHE, National Socialists, S. 140; BING, International Congress, S. 197.

229 Frank, wörtliche Wiedergabe in BING, International Congress, S. 197.

230 Ebd., S. 198.

231 BING, International Congress, S. 198.

232 The Times, 26. August 1935, S.9, Sp. d.

233 Alexander Paterson an Dr Schafer, 17. September 1935, TNA, PCOM 9/196-33 International Penitentiary Congress Berlin 1934-1936, zit. nach ForsYTHE, National Socialists, S. 141.

234 Alexander Paterson und Lord Polwarth an das Home Office, 19. November 1935, TNA, HO 45-20458-553922/52, siehe ForsYTHE, National Socialists, S. 141.

235 Geoffrey Bing, hier zit. nach Negley J. Teeters, Deliberations of the International Penal and Penitentiary Congresses. Questions and Answers 1872-1935, Philadelphia 1949, S. 178. 
diplomacy. "236 Nach dem Berliner Kongress stuften einige Beamte des Home Office die internationalen Gefängniskongresse generell nur noch als „bewildering and ineffective“237 ein. Der Zweite Weltkrieg vereitelte weitere Kongresse. Erst fünf Jahre nach Kriegsende, 1950, kam der 12. und letzte Kongress zustande. 1955 konstituierte er sich unter dem Dach der Vereinten Nationen neu.

\subsection{Bilanz und Ausblick: Experten, Expertise und der Staat}

Das von Karl Pearson geleitete biometrische Labor am University College in London, in dem die von der Prison Commission geförderte Großstudie The English Convict betreut wurde, war eine britische Ausnahmeerscheinung. Weder auf dem europäischen Kontinent, noch in den USA gab es zu diesem Zeitpunkt eine ähnliche Einrichtung mit ähnlicher methodischer Ausrichtung. Ihre Aufgabe bestand u.a. in der auf Massendaten gestützten statistischen Berechnung biologischer Phänomene. Betrachtet man Aufbau und Ergebnisse der Großstudie, so ist zu bedenken, dass ihrer Abfassung eine heftige öffentliche Debatte zwischen den sogenannten Mendelianern und den Mitarbeitern des biometrischen Labors vorausging, bei der es um die wissenschaftlich adäquatere Methode zur Erschließung des Vererbungsmechanismus ging. Während Mendelianer über hypothetische Modelle den dahinter wirkenden Mechanismus (Erbfaktoren) zu entschlüsseln versuchten, näherten sich Biometriker dieser Frage über die mathematisch bestimmbare Intensität im Auftreten phänotypischer Ähnlichkeiten in Nachfolgepopulationen und über die Bestimmung ihrer Beziehungen zu multiplen äußeren Faktoren an. In beiden Fällen bestimmten Vorannahmen im Verfahren die Konstruktion des Untersuchungsgegenstandes. Während die Mendelianer unter Hinzuziehung der um 1900 neu entwickelten Mutationstheorien die Weitergabe von Veränderungen über manipulierte Keimzellen annahmen und damit das Auftreten neuer Arten glaubten erklären zu können, wurde der Untersuchungsgegenstand der Biometriker stets nur als ,ungewöhnliche', aber niemals ,unnatürliche Abweichung von einem statistisch ermittelten Durchschnitt konstruiert. In Gorings Studie selbst war dann aber die Einführung der criminal diathesis, eine mathematisch bestimmbare Größe der, Geneigtheit` zu kriminellen Handlungen, zwar theoretisch nachvollziehbar, nicht aber die daraus abgeleitete Annahme ihrer tatsächlichen konstitutionellen Existenz. Sie wurde von Groing als mentale Schädigung gedacht, aus der alle sozialen Nachteile erwuchsen, die letztlich zu einer kriminellen Karriere prädestinierten. Gorings Behauptung, diese kriminelle Disposition sei letztlich erblich bedingt, entfachte dann Diskussionen über Determinismus und freien Willen. Die Behörden hielten an der Vorstellung des freien Willens als einer wichtigen regulativen Idee fest, auch wenn er sich empirisch

236 The Times, 21. November 1935, S. 7, Sp. f.

237 Home Office Minutes, 17. Oktober 1935, TNA, HO 45-20458-5539/47. 
schwer nachweisen ließ. Zugleich bemängelten Vertreter der Prison Commission die biostatistische Methode, da diese selbst nichts zur Entdeckung ,mentaler Defektheit' beitrage, sondern nur mit ihrer Gegebenheit operiere, während sich ihre Feststellung traditioneller ärztlicher Anamnese verdanke. Auch der genaue Stellenwert von Anlage und Umwelt auf das menschliche Verhalten ließe sich durch sie nicht so überzeugend bestimmen, wie Goring behauptete.

Aufschlussreich ist Gorings Studie auch aufgrund eines anderen Diskussionszusammenhangs. Sie berührte nämlich die Frage, welche Rolle wissenschaftliche Expertise künftig in politischen Entscheidungsprozessen spielen sollte. The English Convict wurde nicht nur als eine wissenschaftliche Untersuchung über Kriminalität und Kriminelle wahrgenommen, sondern durchaus als eine nach zwei Seiten hin ausgerichtete Streitschrift. Sie kritisierte sowohl die Deutungsansprüche der Mendelianer als auch das methodisch unreflektierte Vorgehen von Sozialreformern und Politikern, die es anscheinend alle vorzogen, individuelle Überzeugungen an die Stelle von wissenschaftlich fundierten Erkenntnissen zu setzen. In der Auseinandersetzung über den Einfluss von Anlage und Umwelt auf menschliches Verhalten hatte Goring beklagt:

The whole trend of recent legislation - following, of course, upon popular opinion - has been affected by the notion of the influence of environment. People believe in the effective action of material things they can see. They may, perhaps, think there is „something in heredity“; but they feel that circumstances make the man and determine his condition $[\ldots]$ and they argue that the original influence of heredity may be augmented, reduced, or entirely overcome, by every kind of environmental influence. ${ }^{238}$

Für die Biometriker um Karl Pearson bedeutete Gorings Studie deshalb den Versuch, ihre eigene biostatistische Arbeit den offiziellen Regierungsstellen zu empfehlen, „in moulding public and so official opinion to a sounder view of the criminal“, wie Pearson selbst bekannte. ${ }^{239}$ Es ging dabei um die Etablierung der Biometrie als prognosefähige Wissenschaft, ${ }^{240}$ d. h. um die Entwicklung eines Selektion und Vererbung adäquat beschreibenden und zuverlässig voraussagenden Modells des Evolutionsprozesses. Dabei sollte demonstriert werden, dass Faktoren wie Vererbung durch natürliche und künstliche Selektion in messbarer Weise auf biologische Populationen Einfluss nahmen, um definitive Effekte in der Nachfolgegeneration auszulösen. Einer mathematischen Technik, die solche Voraussagen erlaubte, wohnte ein großes bevölkerungspolitisches Potenzial inne. ${ }^{241}$ Wäre das biometrische Unternehmen erfolgreich gewesen, so argumentiert Donald MacKenzie, dann hätte man eine vollkommen zuverlässige Technik zur Verfügung gehabt, um "the effects of intervention in one generation on the measurable characteristis of subsequent generations" 242 vorherzusagen. Attraktiv war diese

238 Goring, English Convict, S.337f.

239 PEARson, Goring, S.ix.

240 Vgl. Karl Pearson, Mathematical Contributions to the Theory of Evolution, III: Regression, Heredity and Panmixia, in: Philosophical Transactions of the Royal Society of London, Serie A 187 (1896), S. 259.

241 MacKenzIE, Sociobiologies, S. 264.

242 Ebd. 
Methode deshalb besonders für solche Forscher, die eine langfristige, planvolle Verbesserung der gesamten Population im Auge hatten. Alles hing aber davon ab, dass sich das Auftreten von Schlüsselmerkmalen in nachfolgenden Generationen eindeutig und mit sicherer Voraussage nachweisen ließ. Nur die biometrische Methode schien in der Lage, in dieser Form Massenphänomene analysieren und langfristige Trends ausmachen zu können. ${ }^{243}$ Damit warb das biometrische Labor. ${ }^{244}$

1919, im gleichen Jahr, in dem Pearson das Vorwort für die Neuauflage von Gorings The English Convict verfasste, veröffentlichte er noch einmal seine Abhandlung The Function of Science in the Modern State, die bereits 1902 erschienen war. ${ }^{245}$ Pearson betonte hier die Dringlichkeit staatlicher Wissenschaftsförderung, wie sie in Deutschland selbstverständlich sei. Der Krieg habe gelehrt, dass Wissenschaft für das Überleben des Staates von fundamentaler Bedeutung nicht nur im Krieg selbst, sondern auch in Friedenszeiten sei. ${ }^{246}$ Pearson kämpfte in dieser Schrift für ein größeres Mitspracherecht von Wissenschaftler in den politischen Verwaltungen und gegen die Ignoranz der traditionell ausgebildeten OxbridgeBürokraten:

Only by freeing our state executive from the dominance of minds trained solely on literature and jurisprudence, and recognizing that in the modern state the function of science - science in its broadest sense, namely the observation of facts, physical, organic and mental, and the analysis of the observed sequences - extends not only to every department of administration but to all those branches of national activity, which it is the duty of the true statesman not only to foster, but if necessary to create. ${ }^{247}$

Der Mathematiker Pearson wünschte sich nicht nur mehr Wissenschaftler in der Exekutive, er wünschte sich auch eine systematische Förderung von Wissenschaft und Wissenschaftlern durch den Staat und schließlich die Umsetzung wissenschaftlicher Erkenntnisse in eine aktive Bevölkerungspolitik: „The crowning study of man is man; the highest science is that which deals with human races, and sees

243 Pearson glaubte das Gesetz „of ancestral heredity“ aus beobachtbaren Daten gewinnen zu können, was eine theoriefreie Vorhersage möglich machen sollte, „because the biometric concept of heredity simply summarized what happened in the ,passage of a characteristic from given individuals in one generation to those in the next." (MACKenZIE, Sociobiology, S. 268).

244 Probabilistische Analysen haben heute längst klinische Forschung zu kriminellem Verhalten abgelöst, weil sie dem „criminal profiling“ zuarbeiten können, wenn es darum geht, Verdächtige zu identifizieren und sie zu überwachen; in dieser neuen technokratischen, behavioristischen „managerial criminology“ (Katherine Beckett) geht es jetzt um das Einschätzen von Risiko, nicht mehr um das Wissen einzelner individueller Fälle, vgl. zu diesen Entwicklungen den aufschlussreichen Artikel von HARTCOURT, Actuarial Models.

245 KarL Pearson, The Function of Science in the Modern State, 2. Aufl. Cambridge 1919; 1902 war diese Abhandlung als einleitender Essay zum 32. Bd. der 10. Auflage der ENCYCLOPAEDIA BRITANNICA erschienen; das Vorwort zur 2. Auflage (S.v-vii) datiert auf den 1. Februar 1919.

246 Pearson, Function of Science, S. v.

247 Ebd., S. vi; zu Pearsons sozialer Vision und der Schaffung einer wissenschaftlichen Führungselite in einer neuen, durch Wissenschaft bestimmten allgemeinen Kultur siehe auch Theodore Porter, Statistical Utopianism in an Age of Aristocratic Efficiency, in: Osiris 17 (2002), S. 210-227. 
the causes which lead to their progression and relative dominance. This science, applied to national life, is statecraft,- the art of seeing what makes for national health and for national fitness. "248 Pearson schlug die Schaffung eines State Science Council vor, der aus den Direktoren nationaler Institute (Marine, Militär), den anerkanntesten Professoren ,reiner ' Wissenschaften, den besten Lehrern aus technischen Schulen und Personen zusammengesetzt sein sollte, die große wissenschaftliche Leistungen vorzuweisen hatten. ${ }^{249}$ An dieses Gremium sollte sich die Regierung in schwierigen Fragen wenden, da es weitaus besser als jedes herkömmliche Komitee in der Lage sei, den Staat in allen wichtigen Entscheidungen zu unterstützen. ${ }^{250}$ Pearson selbst räumte allerdings ein, dass die britische Öffentlichkeit erst umdenken müsse, um begreifen zu können, ,that trained intelligence in all functions is the factor which makes for victory in the modern international struggle.“ Für Pearson gehörte die Zukunft jedenfalls der „scientific trained nation." 251

Trotz Pearsons engagiertem Werben ließ sich das britische Innenministerium auf seine Forderung nach einer „closer association of the scientific and governing castes“252 nicht ein. Ein sprunghafter Anstieg von Spezialisten und Experten, besonders von Mathematikern, Statistikern, Ökonomen oder Demographen in Regierungskabinetten und staatlichen und kommunalen Verwaltungen war unmittelbar nach dem Ersten Weltkrieg nicht zu verzeichnen. ${ }^{253}$ Zwar hatte es nach der Reformierung des Staatsdienstes und der Einführung von Prüfungen 1870 (Trevelyan Report) einen Professionalisierungsschub auch im öffentlichen Dienst gegeben und der Bedarf an Expertise war gestiegen. Aber nach wie vor rekrutierte sich die politische Elite in erster Linie aus Oxford und Cambridge. Diese wies in weitaus größerem Maße Abschlüsse in klassischen Sprachen als in Naturwissenschaften auf. Selbst als die britische Regierung während des Ersten Weltkriegs systematischer dazu überging, Expertise außerhalb ihrer Reihen einzuholen, ließ sie sich dabei stärker von Geschäftsleuten und Industriellen beraten als von Wissenschaftlern mit ihrem eher formalisierten Wissen. Insgesamt, so betont Theodore Porter, schuf die Kriegsmobilisierung in Großbritannien im Gegensatz zu Deutschland keine größere administrative oder politische Rolle für die Wissenschaft. 254

248 Pearson, Function of Science, S. 89.

249 Siehe dazu ebd., S. $94 \mathrm{f}$.

250 Ebd., S. 96: „For it would involve specialists in all branches of pure and applied science, having the instruments of research at their disposal and would be essentially practical and national in its character."

251 Beide Zitate: PeArson, Function of Science, S. 97.

252 Ebd., S. 96.

253 Zur schwachen Vertretung von Wissenschaftlern in der englischen Politik nach dem Ersten Weltkrieg siehe auch GarY Werskey, The Visible College, Part 1: High Science and Low Politics, London 1978, S. 19-43.

254 Siehe dazu Porter, Statistical Utopianism, S. 221; zur Suche nach Expertise außerhalb der Verwaltung siehe Roy MACLEOD (Hrsg.), Government and Expertise: Specialists, Administrators, and Professionals, 1860-1919, Cambridge 1988. 
Die Vorbehalte, die 1902 Winston Churchill in seiner Antwort auf H.G. Wells Anticipations of the Reaction of Mechanical Progress upon Human Life and Thought gegen Experten formulierte, brachten eine politische Skepsis zum Ausdruck, die viele seiner Zeitgenossen teilen. „Nothing“, schrieb Churchill an Wells, „would be more fatal than for the Government of States to get in the hands of experts. Expert knowledge is limited knowledge, and the unlimited ignorance of the plain man who knows where it hurts is a safer guide than any rigorous direction of a specialized character. Why should you assume that all except doctors, engineers, etc., are drones or worse?" 255 Nicht antimodernes Denken, das sich gegen die fortschreitende Professionalisierung vieler Berufszweige stemmte, bestimmte Churchills Überlegungen, ${ }^{256}$ sondern die Frage, ob spezialisiertes Expertenwissen für die Lösung der höheren Staatsaufgaben überhaupt eine angemessene Wissensform bereitstellte. Zugleich klang hier eine zivilgesellschaftliche Besorgnis an: Die Autorität, mit der Experten auftraten, konnte die offene demokratische Debattenkultur bedrohen.

Die Skepsis gegenüber der Rolle von Experten im Staat war keineswegs eine ganz neue Diskussion in Großbritannien. Bereits John Stuart Mill hatte 1859 in seiner Schrift On Liberty anlässlich der Diskussion über die Einführung von Beamtenexamen ein Gedankenexperiment entworfen: Was würde geschehen, wenn alle Talente des Landes im Regierungskörper (governing body) integriert wären? Er sah zwei Probleme: Zum einen wäre es unmöglich, von außen als Gesellschaft gegen die Entscheidungen eines solchen an Talenten und Wissen überlegenen Körpers zu opponieren, folglich geriete die Gesellschaft in wachsende Abhängigkeit von diesem regierenden Körper, der selbst immer mehr an Macht gewönne. Zugleich würde aber dieser alle Talente aufsaugende Regierungskörper mit großer Wahrscheinlichkeit seine eigene Progressivität einbüßen und in selbstgefällige Routine versinken:

[T] he only stimulus which can keep the ability of the [governing, S.F.] body itself up to a high standard, is liability to the watchful criticism of equal ability outside the body. It is indispensable, therefore, that the means should exist, independently of the government, of forming such ability, and furnishing it with the opportunities and experience necessary for a correct judgement of great practical affairs. 257

Talente, Begabung, Expertise, Wissen mussten immer auch in der Gesellschaft verbleiben und dort selbst kultiviert und gefördert werden. Auf diese Weise würde die Öffentlichkeit nie sämtliche Erwartungen auf den Staat richten, sondern selbst im Besitz von Mitteln sein, einen politischen oder sozialen Wandel einzuleiten und souverän mit Wissensbeständen umzugehen. Nur wenn Kompetenz in der Zivilgesellschaft verblieb, konnte sich nach Mills Auffassung ein Volk als frei

255 Winston Churchill an H.G. Wells, 17. November 1902 (Wells Collection, University of Illinois, Urbana-Champaign), zit. in HAROLd PERKIN, The Rise of Professional Society. England since 1880, London und New York 1989, S. 169.

256 Als ein solches interpretierte Perkin Churchills Stellungnahme, vgl. ders., Professional Society, S. $169 \mathrm{f}$.

257 JOHn STUART Mill, On Liberty and other Essays, Oxford 1991, S. 125, Hervorhebung S.F. 
bezeichnen. Selbst wenn die Regierung sich auflöse, seien solche kompetenten Zivilgesellschaften, wie z.B. die amerikanische, in der Lage, die Situation demokratisch, d. h. nicht durch einen diktatorischen Putsch, zu meistern: „let them [the Americans, S.F.] be left without a government, every body of Americans is able to improvise one, and to carry on that or any other public business with a sufficient amount of intelligence, order, and decision. This is what every free people ought to be: and a people capable of this is certain to be free“. 258 .

Nicht nur in der britischen Verwaltung stießen Karl Pearsons Hinweise auf das leuchtende Wissenschaftsvorbild Deutschland auf Ablehnung und Skepsis. ${ }^{259}$ Auch in der britischen Öffentlichkeit fand er wenig Zustimmung. So warnte Gilbert Keith Chesterton, der Schöpfer der Pater Brown Romane, vor einem „scientifically organised state " und "the modern craze for scientific officialism and strict social organisation“.260 England sei in den Krieg gezogen gegen „the model State of all those more rational moralists who saw in science the ordered salvation of society“, mit anderen Worten: „She [England, S.F.] went to war with [...] Dr. Karl Pearson. "261 Obgleich ein streitbarer Katholik, argumentierte Chesterton in seiner Kritik am eugenischen Programm, das auch durch Gorings Studie gestärkt wurde, nicht primär theologisch oder religiös, sondern staatspolitisch. Ähnlich wie Donkin warnte er vor einer allzu großen Nähe von Wissenschaft und Politik, weil demokratische Prozesse nicht von wissenschaftlichen Rationalitätskriterien bestimmt werden dürften. Das, was Fortschritt und Zivilisation auszeichne, vor allem die Errungenschaft politischer Rechte jedes Einzelnen, werde durch eugenische Eingriffe zutiefst verletzt: ,as if one had a right to dragoon and enslave one's fellow citizens as a kind of chemical experiment." 262 Auch wenn die katholische Kirche Heirat und Familiengründung von jeher zu ihren Zuständigkeitsbereichen zählte, beide waren auch politisch zugesicherte Rechte: „Far into the unfathomable past of our race we find the assumption that the founding of a family is the personal adventure of a free man". 263 Was für das Verhältnis von Politik und Wissenschaft bzw. Eugenik gelten sollte, sollte schließlich auch für das Verhältnis von Rechtsprechung und Wissenschaft gelten. Gegen die Naturalisierung des Strafrechts erinnerte Chesterton an die gewachsenen Strukturen der englischen Rechtstradition und Rechtsstaatlichkeit:

It is also the plain fact that all that has been called civilisation or progress, justice or liberty, [...] has had the general direction of treating even the captive as a free man, in so far as some clear case of some defined crime had to be shown against him. All laws meant allowing the criminal, within some limits or other, to argue with the law. [...] But the criminal is, among civilised men, tried by one law for one crime for a perfectly simple reason: that the motive of the crime, like the meaning of the law, is conceivable to the common intelligence. A man is punished specially as

258 Ebd., S. 124.

259 Pearson hatte in Deutschland studiert und aus Begeisterung seinen Vornamen von Charles in Karl geändert.

260 Gilbert Keith Chesterton, Eugenics and Other Evils, London u. a. 1922, S. 1.

261 Alle Zitate: ebd., S. 182.

262 Ebd., S. 18, Hervorhebung S.F.

263 Ebd., S. 9 f. 
a burglar, and not generally as a bad man, because a man may be a burglar and in many other respects not be a bad man. ${ }^{264}$

Chesterton wusste prominente Publizisten des römisch-katholischen Lagers wie Father Thomas Gerrad ${ }^{265}$ und Hilaire Belloc auf seiner Seite. 1924 erschien in der Catholic Times ein offener Brief des Dekans Vincent McNabb, der deutlich machte, welche Gestalt Wohltätigkeit und Gemeinwohl unter eugenischen Vorzeichen annehmen würde: „Having been begun in order to aid the poor, they would end with eugenic schemes to eliminate the poor." 266 Lange vor dem Erscheinen der päpstlichen Enzyklika De Casti Connubii im Jahr 1930 war in Großbritannien die katholische Kritik an der von der EES propagierten Eugenik längst formuliert. Den englischen Eugenikern erschien die päpstliche Verlautbarung zwar als „defiant return to mediaevalism",267 aber als sie in den Zwischenkriegsjahren einen Gesetzentwurf zur freiwilligen Sterilization auf den Weg bringen wollten, war es die mächtige Koalition aus Labour Party und Katholischer Kirche, die den Versuch bereits in seinen Ansätzen vereitelte. ${ }^{268}$ Der letzte englische Untersuchungsausschluss (Brock Committee), der sich Anfang der 1930er Jahre unter dem Vorsitz des Eugenikers Alfred Tredgold mit der Frage freiwilliger Sterilisation beschäftigte, brachte seinen Gesetzentwurf nicht einmal zur Lesung ins Unterhaus: „[W]e know far too little of the extent and mechnisms of the transmission of feeblemindedness“, warnte S. Davies in seinem Buch Social Control of the Mentally Deficient im Vorfeld der Debatten, „to justify so drastic a preventive measure as sterilisation." 269

Von Bedeutung war hier auch, dass spätestens mit dem Sieg über Deutschland nach dem Ersten Weltkrieg die öffentliche Diskussion über eine mögliche nationale Degeneration in Großbritannien verstummt war. Als die Prison Commissioner in Berlin am 11. Internationalen Gefängniskongress teilnahmen, kamen sie, wie in Kapitel 4 und 5 gezeigt, aus einem Land, das bereits eine prononcierte öffentliche Debatte über Eugenik geführt hatte. In ihrer dezidierten Haltung gegenüber der nationalsozialistischen Ideologie kam nicht nur die persönliche Überzeugung einiger Beamter zum Ausdruck, ${ }^{270}$ sie spiegelte auch die politische Haltung vieler britischer Bürger wider, darunter besonders die Sozialreformer um die Howard League. Wenn Sterilisation schon keine Option für die Gruppe der geistig behinderten oder defizitären Personen war, dann noch viel weniger für Straf-

264 Ebd., S. 35, Hervorhebung S.F.

265 Father Thomas J. Gerrad, ,The Catholic Church and Race Culture', in: Dublin Review 149 (1911), S. 55-67; ders. The Church and Eugenics, London 1912; siehe RiCHARDSON, Love and Eugenics, S. 220-224.

266 Very Reverend Vincent MCNABb in: The Catholic Times (1924), hier zit. nach Richardson, Love and Eugenics, S. 221.

267 Eugenics ReVIEW 23 (1931-1932), S. 41.

268 Vgl. dazu JOHn MACNICOL, Eugenics and the Campaign for Voluntary Sterilization in Britain between the Wars, in: Social History of Medicine 2 (1989), S. 147-169, bes. S. 162.

269 S.P. DAvIES, Social Control of the Mentally Deficient, London 1930, hier zit. nach der Buchbesprechung in MiND 40 (1931), S. 388-390, hier S. 390.

270 Siehe dazu ausführlicher Kap. 7.1. 
täter. Prison Commissioner wie Sir Horatio Byran Donkin und Sir William Norwood East sprachen sich entschieden gegen die Sterilisation von Straftätern aus und eine entsprechende Haltung vertraten auch die britischen Teilnehmer des Internationalen Gefängniskongresses in Berlin 1935. Schon Sir Evelyn RugglesBrise, der 1910 in Washington gerade zum neuen Präsidenten des Internationalen Gefängniskongresses gewählt worden war, hatte mit Bestimmtheit das Angebot seiner amerikanischen Kollegen abgelehnt, auf der zum Beiprogramm des Kongresses gehörenden Besichtigungstour amerikanischer Gefängnisse auch der Sterilisation eines Gewohnheitsverbrechers beizuwohnen. ${ }^{271}$ Bereits auf seiner ersten Amerikareise 1897 hatte der Vorsitzende der Prison Commission vermerkt: „There is not much for us to envy or to copy in the American System. "272 In den öffentlichen Behörden und Gefängnisverwaltungen von England und Wales wurde die Sterilisation von Kriminellen zu keinem Zeitpunkt ernsthaft in Erwägung gezogen worden.

271 Die Geschichte wurde von Colonel Rogers überliefert, der Ruggles-Brise auf seiner Amerikareise 1910 begleitet hatte; es handelte sich um die Sterilisation eines schwarzen ,Gewohnheitsverbrechers` im Gefängnis von Jacksonville, siehe LESLIE (Hrsg.), Ruggles-Brise, S. 161. 272 Zit. ebd., S. 112. 